ano 15 - n. 61 I julho/setembro - 2015

Belo Horizonte I p. 1-270 I ISSN 1516-3210

A\&C - R. de Dir. Administrativo \& Constitucional

Revista de Direito ADMINISTRATIVO \& CONSTITUCIONAL

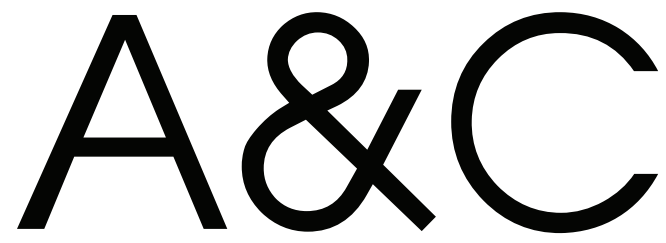




\section{A\&C - REVISTA DE DIREITO ADMINISTRATIVO \& CONSTITUCIONAL}

IPDA

Instituto Paranaense

de Direito Administrativo
ROMEU DEUPE

BACELLAR

๑) 2015 Editora Fórum Ltda.

Todos os direitos reservados. É proibida a reprodução total ou parcial, de qualquer forma ou por qualquer meio eletrônico ou mecânico, inclusive através de processos xerográficos, de fotocópias ou de gravação, sem permissão por escrito do possuidor dos direitos de cópias (Lei no 9.610, de 19.02.1998).

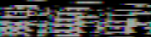

Luís Cláudio Rodrigues Ferreira

Presidente e Editor

Av. Afonso Pena, 2770 - 16ํandar - Funcionários - CEP 30130-007 - Belo Horizonte/MG - Brasil - Tel.: 08007043737 www.editoraforum.com.br / E-mail: editoraforum@editoraforum.com.br

Impressa no Brasil / Printed in Brazil / Distribuída em todo o Território Nacional

Os conceitos e opiniões expressas nos trabalhos assinados são de responsabilidade exclusiva de seus autores.

A246 A\&C : Revista de Direito Administrativo \&
Constitucional. - ano 3, n. 11, jan./mar.
2003)- . - Belo Horizonte: Fórum, 2003-
Trimestral
ISSN: 1516-3210
Ano 1, n. 1, 1999 até ano 2, n. 10, 2002 publicada
pela Editora Juruá em Curitiba
$\begin{aligned} & \text { 1. Direito administrativo. 2. Direito constitucional. } \\ & \text { I. Fórum. } \\ & \text { CDD: } 342 \\ & \text { CDU: } 342.9\end{aligned}$

Supenvisão editorial: Leonardo Eustáquio Siqueira Araújo

Capa: Igor Jamur

Projeto gráfico: Walter Santos

\section{Periódico classificado no Estrato A1 do Sistema Qualis da CAPES - Área: Direito.}

Revista do Programa de Pós-graduação do Instituto de Direito Romeu Felipe Bacellar (Instituição de Pesquisa e Pós-Graduação), em convênio com o Instituto Paranaense de Direito Administrativo (entidade associativa de âmbito regional filiada ao Instituto Brasileiro de Direito Administrativo). A linha editorial da $A \& C$ - Revista de Direito Administrativo \& Constitucional segue as diretrizes do Programa de Pós-Graduação do Instituto de Direito Romeu Felipe Bacellar em convênio com o Instituto Paranaense de Direito Administrativo. Procura divulgar as pesquisas desenvolvidas na área de Direito Constitucional e de Direito Administrativo, com foco na questão da efetividade dos seus institutos não só no Brasil como no direito comparado, com ênfase na questão da interação e efetividade dos seus institutos, notadamente América Latina e países europeus de cultura latina.

A publicação é decidida com base em pareceres, respeitando-se o anonimato tanto do autor quanto dos pareceristas (sistema double-blind peer review).

Desde o primeiro número da Revista, $75 \%$ dos artigos publicados (por volume anual) são de autores vinculados a pelo menos cinco instituições distintas do Instituto de Direito Romeu Felipe Bacellar.

A partir do volume referente ao ano de 2008 , pelo menos $15 \%$ dos artigos publicados são de autores filiados a instituições estrangeiras.

Esta publicação está catalogada em:

- Ulrich's Periodicals Directory

- RVBI (Rede Virtual de Bibliotecas - Congresso Nacional)

- Library of Congress (Biblioteca do Congresso dos EUA)

A\&C - Revista de Direito Administrativo \& Constitucional realiza permuta com as seguintes publicações: - Revista da Faculdade de Direito, Universidade de São Paulo (USP), ISSN 0303-9838

- Rivista Diritto Pubblico Comparato ed Europeo, ISBN/EAN 978-88-348-9934-2 
Diretor-Geral

Romeu Felipe Bacellar Filho

Diretor Editorial

Paulo Roberto Ferreira Motta

Editores Acadêmicos Responsáveis

Daniel Wunder Hachem

Ana Cláudia Finger

Assessor Editorial

Felipe Klein Gussoli

\section{Conselho Editorial}

Adilson Abreu Dallari (PUC-SP) Juan Pablo Cajarville Peluffo (Universidad de La República - Uruguai) ardo Schier (Instituto Bacellar) Justo J. Reyna (Universidad Nacional del Litoral - Argentina)

Alice Gonzalez Borges (UFBA) Juarez Freitas (UFRGS)

Carlos Ari Sundfeld (FGV-SP) Luís Enrique Chase Plate (Universidad Nacional de Asunción - Paraguai)

Carlos Ayres Britto (UFSE) Marçal Justen Filho (UFPR)

Adriana da Costa Ricardo Schier (Instituto Bacellar)
Alice Gonzalez Borges (UFBA)

Marcelo Figueiredo (PUC-SP)

Márcio Cammarosano (PUC-SP)

Carlos Delpiazzo (Universidad de La República - Uruguai) Cármen Lúcia Antunes Rocha (PUC Minas) Célio Heitor Guimarães (Instituto Bacellar) Celso Antônio Bandeira de Mello (PUC-SP) Clèmerson Merlin Clève (UFPR) Clovis Beznos (PUC-SP) Edgar Chiuratto Guimarães (Instituto Bacellar) Maria Cristina Cesar de Oliveira (UFPA)

Nelson Figueiredo (UFG)

Odilon Borges Junior (UFES)

Pascual Caiella (Universidad de La Plata - Argentina)

Emerson Gabardo (UFPR)

Paulo Eduardo Garrido Modesto (UFBA)

Paulo Henrique Blasi (UFSC)

Enrique Silva Cimma (Universidad de Chile - Chile) Eros Roberto Grau (USP)

Irmgard Elena Lepenies (Universidad Nacional del Litoral - Argentina) de La Coruña - Espanha)

Pedro Paulo de Almeida Dutra (UFMG)

Regina Maria Macedo Nery Ferrari (UFPR)

Rogério Gesta Leal (UNISC)

Rolando Pantoja Bauzá (Universidad Nacional de Chile - Chile)

Sergio Ferraz (PUC-Rio)

Valmir Pontes Filho (UFCE)

José Eduardo Martins Cardoso (PUC-SP)

José Luís Said (Universidad de Buenos Aires - Argentina) José Mario Serrate Paz (Universidad de Santa Cruz - Bolívia)

Yara Stroppa (PUC-SP)

\section{Homenagem Especial}

Guillermo Andrés Muñoz (in memoriam) Jorge Luís Salomoni (in memoriam) Julio Rodolfo Comadira (in memoriam) Lúcia Valle Figueiredo (in memoriam)

Manoel de Oliveira Franco Sobrinho (in memoriam) Paulo Neves de Carvalho (in memoriam) 


\title{
O poder de veto da bancada empresarial no Congresso: um veto player emergente na teoria de George Tsebelis*
}

\author{
Henrique Rangel \\ Mestrando em Teorias Jurídicas Contemporâneas - Programa de Pós-Graduação em Direito \\ da Universidade Federal do Rio de Janeiro (Rio de Janeiro - RJ). Técnico Judiciário - Tribunal \\ Regional do Trabalho da Primeira Região. E-mail: <henriquerangelc@gmail.com>.
}

\section{Carlos Bolonha}

Professor Permanente do Programa de Pós-Graduação em Direito da Universidade Federal do Rio de Janeiro (Rio de Janeiro - RJ). Doutor em Teoria do Estado e Direito Constitucional Pontifícia Universidade Católica do Rio de Janeiro. Professor Adjunto e Vice-Diretor Faculdade Nacional de Direito da Universidade Federal do Rio de Janeiro. Diretor do Centro de Pesquisa e Documentação - Ordem dos Advogados do Brasil, subseção Rio de Janeiro. E-mail: <bolonhacarlos@gmail.com>.

\section{Fabrício Faroni}

Mestrando em Teorias Jurídicas Contemporâneas - Programa de Pós-Graduação em Direito da Universidade Federal do Rio de Janeiro (Rio de Janeiro - RJ). Procurador Federal Procuradoria Federal Especializada do Instituto Nacional do Seguro Social. E-mail: <faroni@ uol.com.br>.

Resumo: O presente artigo parte do problema ora intitulado distorção majoritária, caracterizado, basicamente, pelo domínio de instituições representativas por elites ou grupos minoritários da sociedade devido a sua capacidade de organização política. Nesta lógica, o objeto especificado pela pesquisa é a bancada empresarial presente no Congresso Nacional brasileiro. A hipótese formulada questiona se esta bancada teria assumido papel de veto player no sistema político brasileiro. Partindo-se da teoria de George Tsebelis (teoria dos veto players) e criticando-a por não vislumbrar a possibilidade de preferências ou atores políticos diversos emergirem diante de situações concretas, alguns casos emblemáticos são investigados a fim de comprovar a atuação desta forma suprapartidária de organização, sobretudo destacando o caráter conservador de seu comportamento. 0 objetivo desta pesquisa é demonstrar como elites ou grupos minoritários podem causar impacto na política em detrimento dos interesses de segmentos mais numerosos da sociedade.

* Este artigo foi elaborado no âmbito do Laboratório de Estudos Teóricos e Analíticos sobre o Comportamento das Instituições (LETACI), vinculado à Faculdade Nacional de Direito (FND) e ao Programa de Pós-Graduação em Direito (PPGD) da Universidade Federal do Rio de Janeiro (UFRJ), financiado pelo Conselho Nacional de Desenvolvimento Científico e Tecnológico (CNPq), no âmbito do Edital Universal no 14/2013, e pela Fundação Carlos Chagas Filho de Amparo à Pesquisa do Estado do Rio de Janeiro (FAPERJ), no âmbito das concorrências do Auxílio à Pesquisa, APQ-1, 2013, e do Edital no 41/2013, do Programa de Apoio a Grupos Emergentes de Pesquisa no Estado do Rio de Janeiro. Sinceros agradecimentos aos pesquisadores Carlos Cezar de Azevedo Júnior e Felipe Ramirez Gullo, pesquisadores do LETACl que, com assistência, discussões, críticas e propostas, contribuíram para a elaboração do presente trabalho. 
Palavras-chave: Desenhos Constitucionais. Poder Legislativo. Teoria dos Veto Players. Bancada Empresarial. Comportamento Institucional.

Sumário: I Introdução - II A teoria dos veto players de George Tsebelis - III O problema da emergência na teoria dos veto players - IV A bancada dos empresários no Congresso Nacional - V O exercício do poder de veto: casos emblemáticos - Vı Conclusão - Referências

\section{| Introdução}

As teorias clássicas sobre a separação de poderes costumam sustentar que a função de um Congresso é representar o interesse de seus cidadãos. Uma instituição política, após investida de sua incumbência representativa, passaria a perseguir os anseios da nação. Por mais que "nação" seja um conceito reputado de forte indeterminação, esta é uma categoria certamente genérica que não pretende se restringir a grupos minoritários ou elites presentes na sociedade. Por mais que o conceito de maioria legislativa se encontre relativamente mitigado pelo fortalecimento das doutrinas e teorias constitucionais que valorizam direitos das minorias, a legislação mantém seu papel de criar o direito a partir da conjugação dos interesses de distintos segmentos da sociedade.

Em princípio, qualquer destes segmentos detém potencial para eleger seus representantes e defender seus interesses. Na lógica majoritarista, esta influência na construção da instituição política tende a se desequilibrar, de modo que segmentos mais numerosos da sociedade, em tese, elegeriam um número mais elevado de representantes e estariam mais bem assegurados seus interesses em relação aos demais. ${ }^{1}$ Existem teorias que compreendem este fenômeno majoritário como uma ameaça aos grupos minoritários da sociedade e, portanto, questionam a legitimidade

\footnotetext{
O termo "majoritarista" está diretamente associado ao controvertido conceito de "maioria". Trata-se de uma categoria que recebe severas críticas na teoria constitucional norte-americana, devido a seu frequente uso indiscriminado e impreciso. Em determinadas pesquisas, o termo "maioria" é tratado a partir da opinião pública, uma categoria, talvez, ainda mais problemática e de difícil enquadramento. Como exemplo, Cf. POST, Robert; SIEGEL, Reva. Roe Rage: Democratic Constitutionalism and Backlash. Harvard Civil Rights-Civil Liberties Law Review, v. 42, 373, 2007. Em outros trabalhos, no entanto, é possível encontrar "maioria" definida a partir de critérios objetivos. Quando se pretende constatar o que seria a "maioria" da nação em determinado assunto, um critério objetivo pode ser analisar o tratamento da matéria em cada Estado-Membro da Federação método que dependerá da forma de Estado e da distribuição das competências correspondente. A título exemplificativo, o emblemático precedente Brown vs. Board of Education é analisado com base nos avanços da legislação de cada Estado norte-americano, concluindo que a decisão da Suprema Corte não teria sido tão contramajoritária como se costuma sustentar - a maioria dos Estados já havia, àquela época, tomado as medidas cabíveis no combate à discriminação racial observada neste julgado. Cf. BALKIN, Jack. What Brown teaches us about constitutional theory. Virginia Law Review, v. 90, 6, 2004. De maneira similar, visando maior objetividade, termos como "maioria" e "majoritarista" deverão ser considerados, para os propósitos do presente trabalho, de acordo com o número de representantes eleitos no Congresso Nacional. Quanto a isso, é preciso especificar que as análises aqui empreendidas não focam divisões estritamente partidárias, sendo mais adequado comparar o número de representantes vinculados a bancadas e frentes parlamentares em termos relativamente, ou seja, o número de defensores da bancada empresarial confrontado com o número de defensores de bancadas sindicais, religiosas, entre outras. No entanto, cabe ressaltar que a pesquisa não atribui valor absoluto a este critério definidor de "maioria", sendo o mesmo relativizado pela categoria da distorção majoritária, que será apresentada a seguir.
} 
da instituição representativa. Esta tendência, no entanto, nem sempre é observada na prática. O problema que esta pesquisa enfoca é que grandes grupos da sociedade podem, de fato, eleger uma proporção majoritária de representantes, mas o critério numérico nem sempre se sustenta. Se estes grandes segmentos da sociedade não são capazes de se organizar politicamente, outros grupos de menor proporção podem acabar conquistando a instituição política. A capacidade de organização política de um grupo é um fator determinante para a formação de uma instituição representativa que não está presente nas teorias clássicas. ${ }^{2}$ Em certos casos, cria-se uma distorção majoritária: a maioria do Congresso aprova ou reprova projetos políticos a partir do interesse de um grupo minoritário da sociedade. Essa distorção majoritária pode demonstrar, na prática, que o critério numérico nem sempre será determinante, impedindo que as tradicionais teorias democráticas se afirmem como verdadeiras.

No Brasil, particularmente, existem grupos minoritários, sobretudo aqueles que compõem a elite econômica do país, de profunda capacidade de organização política. As principais distorções majoritárias, no desenho constitucional brasileiro, estão relacionadas à expressiva influência do poder econômico na política. Entre os principais atores responsáveis por este fato, característico do sistema político brasileiro, há a bancada empresarial, que atua no Congresso Nacional, e a Confederação Nacional da Indústria (CNI), geralmente utilizada para fins de representação judiciária da categoria empresarial. O presente artigo adota como seu objeto a estrutura legislativa do Congresso Nacional e, especificamente, a influência da bancada empresarial em seus trabalhos. ${ }^{3}$ De modo complementar, a CNI também será objeto

\footnotetext{
2 O processo de organização política pode ser analisado por duas perspectivas. Em primeiro lugar, à época da candidatura, o sucesso nas urnas dependerá, em grande parte, da campanha eleitoral planejada e executada pelo candidato. Uma campanha eleitoral que pretenda prosperar deve captar financiadores. Não é necessária muita reflexão para se concluir quem são os maiores financiadores de campanhas eleitorais. Logicamente, são aqueles que dispõem de maiores recursos econômicos e financeiros: os empresários. Em segundo lugar, após a diplomação, essa capacidade de organização não se desfaz. Embora essa categoria do legislativo aparente ser muito plural e heterogênea, o desacordo acerca de concepções sobre moral e justiça é minimizado pela existência de um critério muito objetivo presente em seus interesses: o lucro. Mesmo aqueles parlamentares que não são eminentemente empresários são persuadidos a defender tais interesses se desejam um bom financiamento para as próximas eleições.

3 A especificação do Congresso Nacional como objeto da pesquisa atende aos ditames do individualismo metodológico. Considerando o conceito de sistema constitucional oferecido por Adrian Vermeule, esta é uma pesquisa que se concentra no primeiro nível de agregação, não havendo a pretensão de se extraírem diretamente conclusões mais genéricas relativas ao sistema constitucional. Busca-se, apenas, aprofundar uma análise do comportamento institucional do Poder Legislativo Federal, viabilizando futuras inserções integradas ao comportamento de outras instituições que constituem o sistema - já em duplo nível de agregação. 0 individualismo metodológico mencionado, portanto, indica que os resultados obtidos no presente trabalho, em tese, não se estendem ao segundo nível de agregação, exigindo-se, para tanto, uma análise sistêmica e complexa que integre o comportamento do Congresso Nacional com o das demais instituições do sistema constitucional brasileiro. Após compreender as propriedades que determinam e caracterizam o funcionamento do Congresso Nacional, apontamentos quanto à interação desta com as demais instituições que com ele compartilham o nível de agregação poderão ser promovidos com menor risco de recair nas chamadas falácias da composição ou da divisão. Para mais detalhes quanto ao conceito de sistema e níveis de agregação adotados, ao uso do individualismo metodológico na análise institucional e esclarecimentos quanto às falácias da composição e da divisão, Cf. VERMEULE, Adrian. The System of the Constitution. New York: Oxford University Press, 2011.
} 
de considerações. Embora sua principal função seja representar judicialmente os interesses da categoria, esta Confederação atua de forma secundária no legislativo, criando anualmente documentos com a finalidade de instruir seus congressistas ao atendimento de seus anseios. ${ }^{4}$

Com base neste problema - a distorção majoritária -, é possível formular a seguinte hipótese: a bancada empresarial, que atua no Congresso Nacional, assumiu a posição de um verdadeiro veto player no sistema político brasileiro. ${ }^{5}$ Para sustentar esta hipótese, é preciso (i) recorrer a uma demarcação teórica que identifique quais atores possuem papel determinante na tomada de decisões do cenário político e (ii) promover uma análise concreta do desenho constitucional brasileiro.

Para atender à primeira necessidade, uma aproximação da teoria dos veto players de George Tsebelis parece ser justificável. ${ }^{6}$ Esta teoria foi construída com o objetivo de redefinir a compreensão das modificações operadas no status quo. Tsebelis não se contenta com análises políticas baseadas em dicotomias heurísticas em que são suficientes as classificações entre presidencialismo e parlamentarismo, bipartidarismo e pluripartidarismo, eleições diretas e indiretas. Ao contrário, sustenta o teórico que identificar os veto players de uma ordem política é algo determinante para entender como mudanças acontecem na política e, mais precisamente, de quem estas alterações mais dependem para ocorrer.

Para atender à segunda necessidade, é indispensável avaliar a estrutura do Congresso Nacional e os influxos recebidos do sistema partidário. Nesta análise concreta do desenho constitucional brasileiro, a pesquisa adota critérios gerais definidores de seu escopo e parâmetros de análise. Quanto aos critérios gerais, temporalmente, a pesquisa se estende ao interstício 1988-2014, justificado pela promulgação da atual Constituição Federal. Espacialmente, a pesquisa restringe-se ao estudo do Governo Federal brasileiro, com ênfase na atuação de seu Poder Legislativo, além de outros atores direta ou indiretamente relacionados ao sistema partidário. Materialmente, são considerados (a) recursos jurídicos, como legislação,

\footnotetext{
4 Trata-se das denominadas Agendas Legislativas da Indústria. Para observar a versão de 2014 deste documento, Cf. CONFEDERAÇÃO NACIONAL DA INDÚSTRIA (CNI). Agenda Legislativa da Indústria. Brasília: Confederação Nacional da Indústria, 2014. Disponível em: <http://www.portaldaindustria.com.br/cni/canal/ agenda-legislativa-home/>. Acesso em: 24 abr. 2014. Além deste papel da CNI, há pesquisas que sustentam seu papel de lobby perante o Poder Legislativo, mas esta abordagem não é abrangida pela presente pesquisa. Nesse sentido, Cf. OLIVEIRA, Rosane Cristina de. Empresariado e Congresso Nacional: um estudo das novas estratégias de ação política: a Firjan e a CNI nos anos 90. Dissertação (mestrado) - UFRJ/IFCS/Programa de Pós-graduação em Ciência Política. 141 fl. Rio de Janeiro: UFRJ/IFCS, 2002. Disponível em: <http://www. livrosgratis.com.br/arquivos_livros/cp027789.pdf>. Acesso em: 25 abr. 2014.

5 Conforme será desenvolvido ao longo do texto, veto players podem ser definidos como os sujeitos institucionais ou partidários que uma proposta de alteração do status quo deve convencer para que a mesma seja aprovada. Com isso, um veto player representa, entre outros aspectos, uma instituição ou um agente político com a prerrogativa de impedir que uma tentativa de modificação do status quo se opere. Cf. TSEBELIS, George. Veto Players: How Political Institutions Work. Princeton: Princeton University Press, 2002.

6 TSEBELIS, George. Veto Players: How Political Institutions Work. Princeton: Princeton University Press, 2002.
} 
decisões judiciais, enunciados de súmula e outros documentos oficiais do governo, além de (b) recursos políticos, como projetos e anteprojetos legislativos, pronunciamentos públicos de oficiais do governo e a atuação de comissões parlamentares, partidos políticos e outras formas de organização representativa. As análises são conduzidas por dois parâmetros: (i) a influência da bancada empresarial no Congresso Nacional e, complementarmente, (ii) a influência da CNI no Congresso Nacional.

O objetivo geral deste artigo é demonstrar como a elevada capacidade de organização política de grupos minoritários da sociedade pode fortalecer significativamente seu poder de veto no Legislativo, sobretudo, dificultando a aprovação de mudanças políticas relevantes desejadas por outros segmentos mais numerosos.

\section{A teoria dos veto players de George Tsebelis}

A teoria dos veto players de Tsebelis contribui para a teoria institucional ao oferecer recursos conceituais e metodológicos para se compreender a lógica de sistemas políticos a partir de seus atores. Na obra que sintetiza a teoria elaborada por Tsebelis, seu objetivo de criar um modelo genericamente aplicável é expressamente declarado: “[o] objetivo é oferecer uma teoria para análises institucionais, sujeitá-la a múltiplos testes e, como resultado, atribuir-lhe um elevado nível de confiabilidade se ela for corroborada em diversas configurações." ${ }^{77}$ A importância dos atores políticos nessa teoria pode ser constatada pelo próprio argumento de Tsebelis, segundo o qual propostas que visam mudanças políticas - ou seja, mudanças no status quo legislativo - dependem da concordância de determinados atores individuais ou coletivos. ${ }^{8}$

De acordo com este argumento, uma definição de veto player já pode ser extraída. Veto player é a representação conceitual atribuída a atores políticos, individuais ou coletivos, que possuem a prerrogativa de impedir a aprovação de mudanças no status quo legislativo. ${ }^{9}$ Devido a esta definição, Tsebelis ressalta, em diversas oportunidades, que toda alteração do status quo legislativo se opera por uma decisão unânime dos veto players - mesmo que atores coletivos tenham concordado segundo uma regra majoritária. ${ }^{10}$ Tsebelis parte do princípio de que "nenhum player

7 No original: "The goal is to provide a theory of institutional analysis, subject it to multiple tests, and, as a result, have a higher level of confidence by corroborating it in several different settings" (TSEBELIS, George. Veto Players: How Political Institutions Work. Princeton: Princeton University Press, 2002. p. 2).

8 "In a nutshell, the basic argument of the book is the following: In order to change policies - or, as we will say henceforth, to change the (legislative) status quo - a certain number of individual or collective actors have to agree to the proposed change. I call such actors veto players" (TSEBELIS, George. Veto Players: How Political Institutions Work. Princeton: Princeton University Press, 2002. p. 2, grifos no original).

9 "In this chapter I define the fundamental concepts I will use in this book, in particular veto players and policy stability. [...] Veto players are individual or collective actors whose agreement is necessary for a change of the status quo. It follows that a change in the status quo requires a unanimous decision of all veto players" (TSEBELIS, George. Veto Players: How Political Institutions Work. Princeton: Princeton University Press, 2002. p. 19).

10 A título de exemplo: "As noted, all decisions must be made by unanimity [...]" (TSEBELIS, George. Veto Players: How Political Institutions Work. Princeton: Princeton University Press, 2002. p. 21). 
racional, dada a alternativa, poderia aceitar um resultado que ele não preferisse ao status quo". ${ }^{11}$

O próprio argumento da teoria já evidencia uma diferenciação entre os veto players - individuais ou coletivos. Esta, porém, não é a única diferenciação possível entre os atores políticos. Com base na origem de tais atores, Tsebelis indica que estes podem ser veto players institucionais e partidários. Atores institucionais derivariam de disposições diretas da Constituição, enquanto atores partidários derivariam do sistema político vigente. ${ }^{12}$ Por um lado, de acordo com Tsebelis, seriam atores políticos institucionais a Câmara dos Deputados, o Senado Federal e a Presidência da República. Tsebelis não aborda Cortes Constitucionais como veto players. Embora a obra Veto Players: How Political Institutions Work não exclua expressamente a possibilidade de Cortes serem atores políticos, uma das consequências das mudanças no status quo legislativo é seu impacto sobre a independência do Judiciário. ${ }^{13}$ Por outro lado, o sistema político de determinado país poderá permitir o surgimento de distintos atores, não necessariamente partidos políticos. Tsebelis qualifica os atores políticos não lastreados pela Constituição como partidários, mas confere uma definição suficientemente aberta para incluir qualquer agente que emirja dos problemas e das características particulares de um sistema político. No caso brasileiro, existem formas de organização suprapartidária que se encaixam perfeitamente nesta definição.

Apesar da diferenciação existente entre atores institucionais e partidários, a análise institucional concreta pode evidenciar que determinada instituição, na verdade, represente rigorosamente um ator partidário que o domina. Tsebelis ressalta esta possibilidade ilustrando-a com a presença de uma maioria expressiva de um partido em uma Casa Legislativa. Nesta hipótese, os interesses e as preferências do ator institucional poderão, de fato, refletir aqueles derivados do partido político

11 No original: "No rational player given the choice would accept any outcome that he does not prefer over the status quo" (TSEBELIS, George. Veto Players: How Political Institutions Work. Princeton: Princeton University Press, 2002. p. 9).

12 "I will call institutional veto players individual or collective veto players specified by the constitution. The number of these veto players is expected to be constant but their properties may change. For example, they may be transformed from collective to individual (if one institution, deciding by simple majority, is controlled by a disciplined party) and vice versa. Also, their ideological distances may vary, so one or more of them may be absorbed. I will call partisan veto players the veto players who are generated inside institutional veto players by the political game. For example, the replacement of a single-party majority by a two-party majority inside any institutional veto player transforms the situation from a single partisan veto player to two partisan veto players. Both the number and the properties of partisan veto players change over time. Parties may lose majorities, they may split, and they may merge and such transformations may have an effect on the number of partisan veto players" (TSEBELIS, George. Veto Players: How Political Institutions Work. Princeton: Princeton University Press, 2002. p. 79).

13 Cf. TSEBELIS, George. Veto Players: How Political Institutions Work. Princeton: Princeton University Press, 2002. 
que o domina. ${ }^{14}$ Mais recentemente, este problema tem sido abordado por autores integrantes do denominado pós-madisonianismo. Em particular, Daryl Levinson e Richard Pildes, em uma severa crítica aos Pais Fundadores e sua compreensão da separação de poderes através das “ambições” e dos checks and balances, argumentam que uma separação de partidos talvez seja uma alternativa mais apropriada para controlar e limitar o governo. ${ }^{15}$

Além do conceito de veto player, Tsebelis trabalha com outros de essencial importância para sua teoria, tais como estabilidade política e composição de agenda. Por um lado, Tsebelis aborda a estabilidade política como a dificuldade de se modificar o status quo, qualificando-o através de algumas variáveis relacionadas ao sistema político, tais como o número de veto players, a distância ideológica entre eles e sua coesão interna para os casos de atores coletivos. ${ }^{16}$ Quanto ao número de veto players, Tsebelis ressalta que a adição de um novo ator político poderá aumentar a estabilidade política - jamais reduzi-la. Porém, a adição nem sempre acarretará aumento na estabilidade política. Isso ocorre devido à regra da absorção. Quando as preferências de um novo ator político se aproximarem daquelas encontradas em

\footnotetext{
14 “Analyzing the political game inside institutional veto players may produce more accurate insights. If veto players are generated by the political game, they are called partisan veto players. For example, it may be that inside the House of Representatives, different majorities are possible, meaning that the House cannot be reduced any further as a veto player. Alternatively, it may be that the House is controlled by a single cohesive party, and the only successful pieces of legislation are those supported by this party. In this case, while the House is the institutional veto player, the majority party is the real (partisan) veto player" (TSEBELIS, George. Veto Players: How Political Institutions Work. Princeton: Princeton University Press, 2002. p. 19, grifos no original).

15 LEVINSON, Daryl; PILDES, Richard. Separation of Parties, Not Powers. Harvard Law Review, v. 119, 1, 2006.

16 "[...] significant departures from the status quo are impossible when the winset is small - that is, when veto players are many - when they have significant ideological distances among them, and when they are internally cohesive. I will call this impossibility for significant departures from the status quo policy stability. [...] The number and the location of veto players affects policy stability, or how difficult it is to change the status quo. The sequence in which veto players make their decisions (who makes proposals to whom) affects the influence that these veto players have in the decisionmaking process. Whether these veto players are individual or collective affects the way they make decisions about policies. If they are individuals (a president or a monolithic political party), they can easily decide on the basis of their preferences. If they are collectives (a parliament or a weak political party), the location of the outcome depends on the internal decisionmaking rule (unanimity, qualified or simple majority) and who controls the agenda. Therefore, traditional political institutions like regime types, or number of chambers of parliament, or number, cohesion, and ideological positions of parties, or decisionmaking rules of all these actors, will be translated into some veto player constellation, which in turn will determine the policy stability of a political system" (TSEBELIS, George. Veto Players: How Political Institutions Work. Princeton: Princeton University Press, 2002. p. 2/17-18). Tsebelis, na verdade, promove uma observação metodológica em seu livro, esclarecendo que a estabilidade política é assumida como ponto inicial de sua pesquisa, indispensável para se estudar os próprios veto players e os resultados do sistema político investigado. Mesmo que o resultado da política não seja diretamente pretendido pelo ator político, existem interesses, como a reeleição, que dependerão dos resultados de sua atividade. "I start my analysis from policymaking (or, more accurately, from legislation and legislating) because policies are the principal outcome of a political system. People participate in a political system in order to promote the outcomes (policies) that they prefer. As a result, policymaking is important for political actors (parties or individual representatives), whether these actors have direct preferences over policies (like De Swaan 1973 assumes) or whether they care simply about reelection (this is Downs' [1957] simplifying assumption), or whether they are ideologically motivated (to follow Bawn's [1999a] approach)" (TSEBELIS, George. Veto Players: How Political Institutions Work. Princeton, NJ: Princeton University Press, 2002. p. 6).
} 
outro já presente naquele sistema, alcançar a unanimidade não será mais desafiador do que antes. Ao contrário, se este novo veto player se distanciar ideologicamente dos demais, a chance de se modificar o status quo será reduzida. ${ }^{17}$ Desse modo, o que Tsebelis denomina "critério numérico" - o número de veto players aumenta a estabilidade política - é relativizado pela regra da absorção, demonstrando como a disposição dos atores políticos gera impacto direto na estabilidade do sistema. ${ }^{18}$ Por outro lado, o poder de agenda é a prerrogativa de oferecer propostas de mudanças do status quo. A iniciativa pode ser vantajosa, pois, entre diversas hipóteses aceitáveis pelos demais veto players, o montador da agenda poderá selecionar a proposta que Ihe seja mais vantajosa ou interessante. Fatores como o número de veto players e sua proximidade ideológica criarão um campo de unanimidade, em que haverá propostas com potencial de aprovação. Entre tais hipóteses, a proposta efetivamente formulada tenderá a estar mais compatível com a orientação do montador da agenda. ${ }^{19}$

Estes dois conceitos - estabilidade política e montagem de agenda -, no entanto, estão relacionados entre si. A importância do poder de agenda, ou seja, a liberdade de escolha do veto playerque inicia a sequência de avaliações das propostas

\footnotetext{
17 A passagem que explica com mais clareza a importância da regra de absorção é a seguinte: “I explain why more veto players lead to higher levels of policy stability. In addition, I show that as distance among veto players becomes greater, policy stability increases and the role of agenda setting decreases. [...] Finally, I demonstrate that the number of veto players is reduced if one of them is located 'among' the others. I provide the conditions under which the addition of a veto player does not affect policy stability or policy outcomes. I call this condition the absorption rule [...]. As a result of the absorption rule a second chamber may have veto power but not affect policy outcomes, or an additional party in coalition government may have no policy consequences because its preferences are located among the preferences of the other coalition partners. One important implication of the absorption rule is that simply counting the number of veto players may be misleading, because a large proportion of them may be absorbed. [...]" (TSEBELIS, George. Veto Players: How Political Institutions Work. Princeton: Princeton University Press, 2002. p. 11-12). Posteriormente, Tsebelis aborda a regra da absorção de modo mais preciso e objetivo: "If there is a unanimity core, its size increases or remains the same with the addition of new veto players. Combining the conclusions of the previous paragraphs leads to the following proposition: Proposition 1.1: The addition of a new veto player increases policy stability or leaves it the same (either by decreasing the size of the winset of the status quo, or by increasing the size of the unanimity core, or by leaving both the same)" (TSEBELIS, George. Veto Players: How Political Institutions Work. Princeton: Princeton University Press, 2002. p. 25).

18 "Proposition 1.2 (absorption rule): If a new veto player D is added within the unanimity core of any set of previously existing veto players, D has no effect on policy stability. [...] Proposition 1.2 is essentially what distinguishes between the verbally awkward accuracy of Proposition 1.1 and the approximate simplicity of the numerical criterion. It explains under what conditions an additional veto player is going to make a difference or is going to be absorbed" (TSEBELIS, George. Veto Players: How Political Institutions Work. Princeton: Princeton University Press, 2002. p. 28-29).

19 "In addition, political institutions sequence veto players in specific ways in order to make policy decisions. The specific veto players that present 'take it or leave it' proposals to the other veto players have significant control over the policies that replace the status quo. I call such veto players agenda setters. Agenda setters have to make proposals acceptable to the other veto players (otherwise, the proposals will be rejected and the status quo will be preserved). In fact, they will select among the feasible outcomes the one they prefer the most. [...] In fact, the player who makes proposals will consider the winset of all the other veto players as his constraint, and select among all the points contained in this winset the one that he prefers. This is the advantage of the agenda setter, identified for the first time formally by McKelvey (1976). Proposition 1.5: The veto player who sets the agenda has a considerable advantage: he can consider the winset of the others as his constraint, and select from it the outcome he prefers" (TSEBELIS, George. Veto Players: How Political Institutions Work. Princeton: Princeton University Press, 2002. p. 2/33-34, grifos no original).
} 
de mudanças do status quo, será maior quando o governo possuir pouca estabilidade política. A estabilidade política, conceituada como a dificuldade de se alterar o status quo - conforme a necessidade de se convencer unanimemente todos os veto players -, reduz o campo de possibilidades do montador de agenda. As hipóteses de provável aprovação estarão cada vez mais distantes de suas preferências, reduzindo seu impacto no sistema político. ${ }^{20}$ Portanto, há uma relação de proporcionalidade inversa entre o poder de agenda e a estabilidade política, que pode ser representado, inclusive, pela fórmula simplificada a seguir (considerem-se: estabilidade política, EP; poder de agenda, PA; e duas variáveis que ajustam as grandezas, a e $b$ ): ${ }^{21}$

$$
E P . a=\frac{1}{P A . b}
$$

A existência de um elevado grau de estabilidade política traz algumas consequências de especial destaque na teoria de Tsebelis. A redução do poder de agenda mencionado acima é uma delas, mas outras também podem ser observadas. Dependendo do sistema de governo, os efeitos podem ser distintos. De um lado, governos parlamentaristas com elevada estabilidade política sofrem um problema de instabilidade governamental. ${ }^{22}$ Embora pareça um contrassenso, cabe ressaltar o que Tsebelis considera objetivamente estabilidade política - a dificuldade de alteração do status quo - e, com isso, o impasse em produzir reformas pode conduzir a um quadro crítico de sucessivas destituições de primeiros-ministros. De outro lado, um governo presidencialista, que confere maior segurança a seu Chefe de Governo, poderia ocasionar instabilidade do regime. ${ }^{23}$ Tsebelis considera que da dificuldade de produzir mudanças no status quo e de substituir o Chefe de Governo pode surgir um regime militar. Além dos problemas de instabilidade de governo e de regime, ocasionados por uma estabilidade política muito elevada, a teoria dos veto players sustenta outras duas consequências comuns: o desenvolvimento de um perfil ativista no Poder

\footnotetext{
20 “As a consequence, agenda-setting powers are inversely related to policy stability: The higher policy stability (meaning the smaller the set of outcomes that can replace the status quo), the smaller the role of agenda setting. In the limit case, where change from the status quo is impossible, it does not make any difference who controls the agenda" (TSEBELIS, George. Veto Players: How Political Institutions Work. Princeton: Princeton University Press, 2002. p. 2-3).

21 Tendo em vista o argumento da proporcionalidade inversa destas categorias - estabilidade política e poder de agenda - na obra de Tsebelis, a fórmula acima foi estruturada pelos coautores para os propósitos da presente pesquisa. Cf. TSEBELIS, George. Veto Players: How Political Institutions Work. Princeton: Princeton University Press, 2002.

22 "The difficulty a government encounters in its attempt to change the status quo may lead to its resignation and replacement in a parliamentary system. This means that policy stability will lead to government instability [...]" (TSEBELIS, George. Veto Players: How Political Institutions Work. Princeton: Princeton University Press, 2002. p. 3).

23 "Similarly, in a presidential system, the impossibility of the political system to resolve problems may lead to its replacement by a military regime ("regime instability" [...])" (TSEBELIS, George. Veto Players: How Political Institutions Work. Princeton: Princeton University Press, 2002. p. 3).
} 
Judiciário e nas burocracias. ${ }^{24}$ Em tese, burocratas e juízes, quando interpretam a legislação, podem atribuir um sentido à norma que Ihes seja mais favorável, seja por preferências institucionais, por conveniência do serviço, por convicções pessoais ou qualquer outro motivo. Quando isso ocorre, há um fenômeno similar ao que ocorre com os montadores de agenda. Uma sequência é iniciada, com uma proposta ao menos de fuga do status quo que poderá ser revertida posteriormente por outro veto player. Assim, os burocratas e os juízes precisam descartar aquelas interpretações que, embora Ihes sejam favoráveis, dificilmente serão aprovadas pelos demais veto players. ${ }^{25}$ Tais consequências não serão as únicas apresentadas pela teoria dos veto players. ${ }^{26}$ Existem outros resultados relativos ao nível de estabilidade de um sistema político. Como exemplo de outras consequências, o próprio caráter da legislação de um país pode ser caracterizado de acordo com sua estabilidade política. Em países de elevada estabilidade política, Tsebelis afirma ser comum se aprovarem, em larga escala, leis pouco significativas, que não promovem grande impacto no status quo. Ao contrário, países de reduzida estabilidade política podem produzir um quantitativo menor de leis, mas estas terão um impacto mais expressivo no sistema político. ${ }^{27}$

\section{O problema da emergência na teoria dos veto players}

A teoria dos veto players é uma teoria voltada para análises institucionais, recaindo sobre aspectos gerais que podem ser aplicáveis sobre sistemas políticos. É importante ressaltar, no entanto, que Tsebelis demonstra grande parte de seu raciocínio baseado em geometria euclidiana. 0 autor recorre a um espaço n-dimensional para representar o sistema político por formas geométricas que, sobrepostas, ilustram como o número de veto players e sua posição no plano criam possibilidades maiores

24 "Finally, the impossibility of changing the legislative status quo may lead bureaucrats and judges to be more active and independent from the political system" (TSEBELIS, George. Veto Players: How Political Institutions Work. Princeton: Princeton University Press, 2002. p. 3).

25 “[...] both the judiciary (when making statutory interpretations) and the bureaucracies can be legislatively overruled if they make choices the (legislative) veto players disagree with, so they are likely to avoid such choices. In fact, both the judiciary and the bureaucracy will try to interpret the law according to their point of view (or perhaps interests) while eliminating the possibility that they will be overruled. [...] In game theoretic terms I describe a sequential game where the bureaucrats or judges make the first move (interpret the existing laws) and the veto players make the second (decide to overrule or not and how)" (TSEBELIS, George. Veto Players: How Political Institutions Work. Princeton: Princeton University Press, 2002. p. 222).

26 Tsebelis apresenta estas cinco consequências de modo mais sistemático, dando-lhes ênfase em seu trabalho, mas, esporadicamente, menciona outros efeitos ao longo de seu livro.

27 "As a result, countries with few veto players produce several significant laws and few nonsignificant ones, while countries with many veto players produce few significant laws and many nonsignificant ones. The chapter ends with the expectation that such systematic differences lead to a different concept of 'law' in different countries" (TSEBELIS, George. Veto Players: How Political Institutions Work. Princeton, NJ: Princeton University Press, 2002. p. 14). 
ou menores de alteração do status quo. ${ }^{28}$ Em muitos momentos, a demonstração geométrica é esclarecedora, possuindo grande relevância didática. O espaço euclidiano, na verdade, possui mais do que um papel didático na teoria dos veto players. Trata-se da base epistemológica da teoria, pois a disposição dos elementos geométricos no plano n-dimensional - o referencial ontológico do sistema político-objeto será determinante para caracterizar seu funcionamento, ditando fenômenos como os níveis de sua estabilidade política, a importância do poder de agenda, a tendência do Judiciário e das burocracias serem ativistas ou não, se algum veto player sofre os efeitos da regra de absorção, em que direção o montador de agenda tende a oferecer alternativas ao status quo, entre outros. Em síntese, dada a disposição ontológica do sistema político-objeto (número de veto players e sua distância ideológica), promove-se a diagramação no espaço euclidiano e, somente então, o funcionamento do sistema político será revelado, demonstrando-se a particular aplicação das categorias epistemológicas da teoria de Tsebelis.

A teoria de Tsebelis contém um embasamento empírico consistente e amplo, mas ao menos uma crítica pode ser feita quanto à representação euclidiana do sistema político: nem sempre haverá uma disposição ontológica do sistema político-objeto contínua e permanente.

Em primeiro lugar, a distância ideológica entre os veto players pode sofrer alterações de acordo com uma controvérsia concreta existente. Mesmo que haja uma disposição padrão, observada com relativas continuidade e frequência em um dado sistema político, situações pontuais, excepcionais ou não, poderão promover um rearranjo na alocação das preferências dos veto players. Uma instituição habitualmente caracterizada como liberal pode, em certos assuntos, comportar-se como radicalmente conservadora por exemplo. Os veto players institucionais ou partidários podem possuir, declaradamente ou não, interesses e preferências mais latentes ou mais intensos de acordo com tema, assunto ou proposta em questão. Esta é uma modificação cuja percepção dependerá de exemplos práticos, sejam eles históricos ou presentes, capazes de justificar a alegada modificação da posição do veto player no sistema. Tais casos serão referidos a partir de então como preferências emergentes.

Em segundo lugar, parece ser um equívoco acreditar que os mesmos veto players formarão um dado sistema político indiscriminadamente. A própria ordem

\footnotetext{
28 Os conceitos de winset of status quo e de core of unanimity, recorrentes na obra de Tsebelis, são os que mais dependem desta demonstração geométrica para que sejam compreendidos. Neste sentido: “I now define two more concepts. The first is the winset of the status quo (W(SQ)), the set of outcomes that can defeat the status quo. Think of the status quo as current policy. The winset of the status quo is the set of policies that can replace the existing one. The second concept is the core, the set of points with empty winset - the points that cannot be defeated by any other point if we apply the decisionmaking rule. I usually refer to the core along with the decisionmaking rule that produces it. For example, the 'unanimity core' refers to the set of points that cannot be defeated if the decision is unanimous. An alternative name for 'unanimity core' that I also use is 'Paret set'" (TSEBELIS, George. Veto Players: How Political Institutions Work. Princeton, NJ: Princeton University Press, 2002. p. 21).
} 
jurídica determina que, em certas hipóteses, diferentes instituições participarão do processo decisório. Além disso, determinadas situações práticas estimulam novos atores políticos a insurgirem - ou a se absterem - na disposição do sistema político-objeto. 0 fato de estes novos atores não protagonizarem o cenário político continua e frequentemente torna difícil sua constatação, sendo ainda mais complexo quando esta insurgência ocorre através de um veto player partidário que se manifesta do interior de um veto player institucional. Como já mencionado, Tsebelis prevê a possibilidade de um partido político dominar um órgão legislativo de tal forma que sua preferência substitui a da própria instituição. ${ }^{29}$ Esta, porém, não é a única situação possível. Determinados assuntos, temas e controvérsias podem despertar uma preferência marcante em parlamentares que independe de sua filiação partidária. Nestes casos, não haverá um veto player partidário se manifestando de dentro - e no lugar de - um veto player institucional, e sim um veto player emergente. Não serão observados comportamentos de acordo com preferências da instituição ou do partido, mas de acordo com outras formas de organização, também com potencial de impacto no sistema político.

Ambos os casos de emergência - de preferências ou veto players - causam uma profunda modificação na disposição do sistema político-objeto, algo que não pode ser extraído diretamente da geometria euclidiana aplicada por Tsebelis. Apesar de a teoria dos veto players ser apropriada para abordar o desenho constitucional brasileiro e possuir recursos empíricos suficientes para sua sustentação, o problema da emergência deve ser ponderado - ao menos para os propósitos do presente trabalho.

Certas tentativas de alteração do status quo legislativo provocam significativas mudanças no que aparenta ser a disposição dos veto players no Brasil. Grupos politicamente organizados conduzem o sistema político brasileiro a determinadas emergências dependendo do tema, assunto ou matéria abordados, sendo marcante a influência das denominadas bancadas e frentes parlamentares. De modo mais preciso, a grande capacidade de organização política de grupos econômicos tem sido determinante ao desfecho de controvérsias políticas relacionadas a seus interesses, o que pode ser ilustrado pela atuação da bancada parlamentar dos

\footnotetext{
29 Do mesmo modo, a hipótese de atores políticos extraordinários, como as Forças Armadas, a burocracia, agentes políticos externos, ou outros grupos de interesse de que a proposta dependa para alterar o status quo, protagonizarem o sistema também é cogitada. Tais atores aqui intitulados extraordinários, que devem ser considerados nas análises, são previstos como permanentes no sistema. Em nenhum momento, Tsebelis indica que tais atores podem surgir espontaneamente no sistema político analisado de acordo com matéria, tema ou assunto abordado pela controvérsia prática. Neste sentido: "If a case can be made that the army, the bureaucracy, or some interest group are veto players in a certain country, their preferences should be included in the analysis" (TSEBELIS, George. Veto Players: How Political Institutions Work. Princeton: Princeton University Press, 2002. p. 35).
} 
empresários..$^{30} \mathrm{Em}$ particular, os casos emblemáticos que serão abordados ao final, ao lado da agenda legislativa da indústria, evidenciam um especial interesse destes grupos em temas concernentes a direitos e garantias trabalhistas e tributação, questões determinantes à contabilização do custo financeiro suportado por empresários.

A teoria dos veto players de Tsebelis evidencia como o sistema político pode ser compreendido a partir dos atores políticos que protagonizam aquele sistema, considerando-se fatores como o número de atores, seu distanciamento ideológico, a influência do poder de agenda, entre outros. Nesta análise político-institucional, no entanto, certas ponderações devem ser promovidas no que tange à emergência de preferências ou de outros veto players que, em geral, não caracterizam a formação regular do sistema político brasileiro.

\section{A bancada dos empresários no Congresso Nacional}

A teoria dos veto players de Tsebelis analisa o sistema político a partir de seus atores. Em geral, esta teoria é apropriada para analisar o sistema político brasileiro, mas ao menos duas dificuldades podem Ihe ser apontadas: a emergência de preferências e a emergência de atores. Com isso, o arranjo dos veto players deixa de ser uma condição ontológica contínua e imutável dependendo da controvérsia concretamente abordada. A sustentação da emergência como crítica parcial à teoria dos veto players permite analisar alguns casos emblemáticos, conferindo a exata relevância da bancada dos empresários em seu desfecho.

De acordo com Tsebelis, um sistema político é composto por atores institucionais e atores partidários, cabendo a esta última espécie uma definição suficientemente abrangente para que se integrem as bancadas e as frentes parlamentares. 0 surgimento de tais formas suprapartidárias de organização pode ser associado a determinados problemas existentes no sistema partidário brasileiro. Podem ser citados como problemas político-partidários brasileiros: o multipartidarismo, a baixa institucionalização dos partidos políticos e a sucessão de partidos. No Brasil, o sistema partidário está fragmentado em trinta e dois partidos regularmente registrados no Tribunal Superior Eleitoral (TSE), vinte e três dos quais possuem representação nacional. ${ }^{31}$ Além dos

\footnotetext{
30 Embora esta forma suprapartidária de organização política tenha se popularizado como bancada parlamentar dos empresários, trata-se, tecnicamente, de uma frente parlamentar. Ambas as formas de organização são suprapartidárias e originadas por razões ideologicamente concentradas - em temas, assuntos ou matérias específicas -, não possuindo uma concepção político-teórica ou político-filosófica geral e abrangente. 0 critério que promove a diferenciação técnica entre bancada e frente parlamentar advém do Ato no 69/2005 da Mesa Diretora da Câmara dos Deputados, que dispõe, em seu art. 2o, o seguinte: “[...] considera-se Frente Parlamentar a associação suprapartidária de pelo menos um terço de membros do Poder Legislativo Federal, destinada a promover o aprimoramento da legislação federal sobre determinado setor da sociedade" (sem ênfase no original). A bancada empresária, portanto, configura-se como uma frente parlamentar por possuir um contingente de signatários superior a este critério normativamente definido. De qualquer modo, o termo “bancada empresária" será empregado ao longo do texto, tendo em vista o uso habitual já existente.

31 Em 24 de setembro de 2013, o TSE deferiu o registro de mais dois partidos políticos: Partido Republicano da Ordem Social (PROS) e Solidariedade (SDD).
} 
aspectos quantitativos, tais partidos políticos se proliferam sem apresentarem, com rigor, seus interesses, projetos e propostas políticas. A dificuldade em se diferenciar as pretensões políticas dos partidos está associada à sua baixa institucionalização. ${ }^{32}$ Tais problemas, por sua vez, somente se agravam com a sucessão de partidos políticos observada. ${ }^{33}$ Tendo em vista a recorrente criação e extinção dos partidos, a razão de sua baixa institucionalização e de sua frágil ideologia pode ser associada justamente a seu tempo de existência. Tanto a organização interna de um partido, quanto a construção de um conjunto de ideias e pensamentos suficientemente coerente são questões que demandam tempo e experiência democrática. Tais problemas esclarecem por que os parlamentares, em sua atuação prática, podem se comportar sem uma rigorosa vinculação ao partido político a que se filiaram no momento da candidatura.

Este problemático contexto político-partidário permite o surgimento de modelos informais de organização política, como as bancadas e as frentes parlamentares. Ao contrário dos partidos, que buscam uma constituição formal para promover pensamentos e ideais abrangentes na política, as bancadas e as frentes parlamentares, reúnem-se com maior grau de informalidade para proteger interesses de maior especificidade como doutrinas religiosas, categorias profissionais, pensamentos ambientalistas ou grupos minoritários politicamente organizados, entre outros. Apesar das diferenças técnicas entre bancadas e frentes, ambas as formas de organização possuem natureza suprapartidária e têm se apresentado com elevada eficácia na implementação de seus programas políticos e, principalmente, na conservação de seus interesses. ${ }^{34}$

As principais frentes e bancadas parlamentares presentes no sistema político brasileiro, organizadas ao redor de assuntos, temas e matérias específicas, são a empresarial, a ruralista, a ambientalista, a religiosa, a evangélica, a sindical,

32 Um exemplo do problema enfrentado pela política brasileira pode ser extraído da discussão existente acerca da fidelidade partidária. Debatia-se sobre a possibilidade de um parlamentar, após eleito e investido em seu mandato, romper seu vínculo com o partido para filiar-se a outro. Esta prática foi reprimida pelo TSE e, igualmente, pela Suprema Corte brasileira. O TSE reprimiu a prática da infidelidade partidária através da Resolução no 22.610/2007, alterada pela Resolução no 22.733/2008, enquanto a Suprema Corte através do precedente MS no 26.603/DF, STF, Plenário, Min. Rel. Celso de Mello. DJe, 19 dez. 2008.

33 Ao fim do ano de 2013, surgiu, no Brasil, uma nova controvérsia. A legislação eleitoral garante algumas questões estratégicas aos partidos políticos. Entre estas, há um repasse de arrecadações aos partidos políticos, proporcional a sua representação no Congresso, oriunda do denominado Fundo Partidário, além de uma quantia de minutos em meios de mídia para divulgação de propaganda eleitoral. Discute-se, no Congresso Nacional, a possibilidade de impedir que parlamentares "infiéis" transfiram recursos financeiros e de comunicação para partidos criados durante a legislatura. O Projeto de Lei da Câmara no 14/2013, de iniciativa do Poder Executivo, ensejou grande repercussão não somente por sua temática, mas por culminar na antecedência de um ano para as eleições presidenciais. Em outubro do mesmo ano, foi publicada a Lei no 12.875/2013, aprovando o PLC no 14/2013, dispondo que os partidos fundidos ou incorporados não serão computados na distribuição dos recursos do Fundo Partidário e do acesso aos recursos de rádio e televisão para fins de propaganda eleitoral gratuita. Além disso, os recursos do Fundo Partidário serão repartidos tendo como critério o resultado da votação da última eleição para a Câmara dos Deputados, desconsiderando-se, portanto, casos de infidelidade partidária ou de sucessão partidária. Estes somente participarão da divisão igualitária de $5 \%$ (cinco por cento) dos recursos do fundo, restando os 95\% (noventa e cinco por cento) para divisão proporcional à representação nacional dos partidos previamente existentes.

34 A conservação de interesses buscada pelas frentes e bancadas parlamentares está muito próxima do conceito de estabilidade política em Tsebelis baseado em status quo. 
bancadas profissionais - saúde, educação e esporte -, entre outras. ${ }^{35}$ Entre estas, a que alcança maior composição é a bancada dos empresários. A influência da denominada bancada dos empresários pode ser esclarecida com um demonstrativo numérico de sua representação nacional. Uma simples análise quantitativa desta representação expressa como a categoria é bem-sucedida em sua organização política e como assuntos vinculados a seus interesses podem provocar a emergência de um ator determinante no cenário político.

Representação da Bancada Empresarial no Poder Legislativo

\begin{tabular}{c|c|c|c}
\hline & $\begin{array}{c}\text { Total de } \\
\text { Parlamentares }\end{array}$ & $\begin{array}{c}\text { Bancada } \\
\text { Empresarial }\end{array}$ & $\begin{array}{c}\text { Representação } \\
\text { Percentual }\end{array}$ \\
\hline $\begin{array}{c}\text { Câmara dos } \\
\text { Deputados }\end{array}$ & $\begin{array}{c}513 \text { Deputados } \\
\text { Federais }\end{array}$ & $\begin{array}{c}246 \text { Deputados } \\
\text { Federais }\end{array}$ & $47,96 \%$ \\
\hline $\begin{array}{c}\text { Senado } \\
\text { Federal }\end{array}$ & $\begin{array}{c}81 \text { Senadores da } \\
\text { República }\end{array}$ & $\begin{array}{c}27 \text { Senadores da } \\
\text { República }\end{array}$ & $32,93 \%$ \\
\hline $\begin{array}{c}\text { Congresso } \\
\text { Nacional }\end{array}$ & 594 Parlamentares & 273 Parlamentares & $45,96 \%{ }^{36}$ \\
\hline
\end{tabular}

Conforme demonstrado na tabela acima, o percentual de parlamentares, tanto nas Casas Legislativas, quanto em números absolutos no Legislativo Federal, afiliados à bancada dos empresários é altamente expressivo. ${ }^{37}$ Embora o número de

35 É importante observar que, em muitos casos, a regra de absorção se aplica também às bancadas ruralista e evangélica, respectivamente absorvidas pela empresarial e pela religiosa. Cf. DEPARTAMENTO INTERSINDICAL DE ASSESSORIA PARLAMENTAR (DIAP). Bancadas Informais no Congresso Nacional em 2011. Radiografia do Novo Congresso: Legislatura 2011-2015. Brasília: Departamento Intersindical de Assessoria Parlamentar, 2010. Disponível em: <http://www.diap.org.br/ diap/images/stories/publicacoesDIAP/Radiografia_011/ Radiografia_011_P35.pdf>. Acesso em: 25 abr. 2013.

36 Destaque-se que o cômputo percentual da representação da bancada empresária no Congresso Nacional não pode ser feito com base na média aritmética dos indicados em cada Casa Legislativa, pois, devido à diferença no quantitativo de parlamentares em cada Casa Legislativa, haveria uma distorção neste caso. Com isso, o cálculo, para expressar o resultado absoluto, baseou-se na soma do número de parlamentares da bancada empresária em função do número total de parlamentares no Congresso Nacional.

37 Tabela produzida originalmente para os fins do presente trabalho pelos coautores. Fonte das informações: Departamento Intersindical de Assessoria Parlamentar (DIAP). Os critérios aplicados para delimitar a composição desta bancada empresarial podem ser sintetizados na passagem a seguir: "São classificados como empresários os parlamentares cuja principal fonte de renda advém dos rendimentos de seus negócios. 0 grupo inclui milionários com aplicação financeira, acionistas e quotistas de empreendimentos em geral, independentemente do setor, lideranças sindicais das categorias econômicas, entre outros. Também compõem essa seleta bancada os parlamentares que mesmo não tendo patrimônio declarado à Justiça Eleitoral se auto-intitulam empresários" (Disponível em: <http://www.diap.org.br/index.php?option=com_content\&view=article\&id=14656\&ltemid=279>. Acesso em: 10 abr. 2013). Embora os critérios aparentem ser abertos, é importante destacar seu caráter legitimador da autoafirmação. Além disso, a atividade empresária pode ser facilmente constatada pelo exercício de atividade industrial, comercial, especulativa, ou qualquer função similar no ramo. 
27 (vinte e sete) Senadores da República não aparente uma proporção tão expressiva de parlamentares vinculados à bancada, este numerário representa exatamente 1/3 (um terço) do quorum desta Casa Legislativa. Por sua vez, a Câmara dos Deputados é a Casa que abarca o maior contingente de representantes do empresariado. Quase a metade dos Deputados Federais defende interesses da categoria empresarial. Como o numerário de parlamentares nesta última Casa Legislativa é amplamente superior ao número de Senadores da República no Congresso Nacional, a média extraída do Legislativo Federal, como um todo, fica muito próxima do valor da Câmara dos Deputados: $46 \%$ aproximadamente. Neste sentido, a bancada empresária supera largamente a proporção exigida para a formação de uma frente parlamentar - um terço do legislativo. Com quase metade de todo o Congresso Nacional, a influência deste ator político, na hipótese de sua emergência, é de significativo impacto, podendo exercer um grande poder de veto no cenário político federal.

O número de parlamentares defensores dos interesses empresariais representa um forte argumento da capacidade de organização política desta categoria. Entretanto, a bancada empresária não é a única forma de organização dos empresários. Além deste peculiar modelo de representação política, os empresários contam com a forma associativa da CNI, com importante atuação no plano do controle judicial e na sistematização de uma agenda política de acordo com os interesses da categoria. A CNI congrega as 27 (vinte e sete) federações da indústria dos Estados e do Distrito Federal, estabelecendo, entre suas funções a representação judicial dos interesses empresariais. Trata-se, portanto, de 2 (dois) mecanismos de representação controlados pela mesma categoria profissional: a bancada empresária e CNI.

\section{O exercício do poder de veto: casos emblemáticos}

A bancada empresária, nos últimos anos, tem assumido, em regra, um comportamento conservador, no sentido de preservar as conquistas políticas de sua categoria no Congresso Nacional - ou seja, manter o status quo legislativo no que Ihe convier. Entre as principais disputas travadas no Poder Legislativo, sua atuação alcançou especial destaque nas seguintes controvérsias: (i) no Projeto de Emenda à Constituição no 231/1995, ainda em tramitação; (ii) na Mensagem no 59/2008 da Presidência da República ao Congresso Nacional; e (iii) da não recepção do art. 192 da CLT pelo art. 7ํㅡㄴ, IV, da Constituição Federal. Na primeira controvérsia, grupos defensores de direitos de natureza trabalhista tentam reduzir a jornada semanal de trabalho, atualmente de 44 (quarenta e quatro) horas, para 40 (quarenta) horas, além de aumentar o adicional da hora extraordinária para $75 \%$ (setenta e cinco por cento) sobre a hora normal de trabalho, atualmente de $50 \%$ (cinquenta por cento). $\mathrm{Na}$ segunda, buscava-se reaplicar, no Brasil, a Convenção no 158/1982, da Organização Internacional do Trabalho (OIT), que proíbe os empresários de praticar a dispensa 
imotivada. ${ }^{38} \mathrm{Na}$ última, tentava-se extinguir uma prática inconstitucional, qual seja, vincular a base de cálculo do adicional de insalubridade ao salário-mínimo, pela reivindicação de sua substituição por uma base de cálculo mais vantajosa ao trabalhador, como, por exemplo, a remuneração total ou o salário básico.

O Projeto de Emenda à Constituição no 231/1995 conta com parecer favorável, emitido por Comissão Especial designada para sua análise pela Mesa Diretora da Câmara dos Deputados, cuja aprovação consta de 30 de junho de 2009. ${ }^{39}$ O projeto já está pronto para ser levado a Plenário, porém, suas únicas movimentações, desde a aprovação do parecer até então, são requerimentos de inclusão na Ordem do Dia, apresentados por congressistas diversos. No total, foram 12 (doze) requerimentos de inclusão na Ordem do Dia frustrados, datados de 12 de agosto e 08 de setembro de 2009; 12 de maio e 03 de agosto de 2010; 03 e 16 de fevereiro, 20 de abril e 26 de maio de 2011; 07 de fevereiro, 07 de março, 02 de agosto e 04 de setembro de $2012 .{ }^{40}$ o projeto, apesar de pronto para votação em Plenário, parece ser contido por organizações políticas cujos interesses Ihe são contrapostos.

38 Esta convenção já fora, anteriormente, aplicada no país, a partir de sua ratificação pelo Decreto nº 1.855/1996. Porém, no mesmo ano de sua ratificação, durante o próprio governo de Fernando Henrique Cardoso, em período usualmente reputado como neoliberal e de flexibilização das relações de trabalho, procedeu-se à denúncia da convenção, deixando a mesma de vigorar por meio do Decreto no 2.100/1996. Nesse sentido: “No âmbito das iniciativas governamentais ou dos atores sociais a respeito da temática 'flexibilidade e direito do trabalho', merece especial destaque o fato de o governo brasileiro ter denunciado a Convenção 158 da OIT, que trata da terminação da relação de trabalho por iniciativa do empregador. Este instrumento normativo internacional, apesar de não cumprido efetivamente na sua plenitude, estava em vigor no Brasil desde janeiro de 1996." SIQUEIRA NETO, José Francisco. "Direito do Trabalho e Fexibilização no Brasil" (São Paulo em Perspectiva, v. 11, n. 1, 1997, p. 38).

39 Este não foi o único projeto legislativo com o propósito de reduzir a jornada máxima de trabalho e alterar o percentual da hora extraordinariamente laborada. Nesse sentido: “Atualmente, esta Proposta [PEC no 231/1995] encontra-se sujeita à apreciação do Plenário, sendo que sua última ação legislativa foi emitida pela Comissão Especial, que aprovou, com emenda, a Proposta e rejeitou as Propostas de Emenda à Constituição no 271/95 e 393/2001, que foram àquela apensadas. A PEC n $271 / 1995$, do Deputado Eduardo Jorge e outros propõe a alteração da redação do inciso XIII do artigo $7^{\circ}$ da Constituição Federal com a finalidade de reduzir a jornada de trabalho de oito para seis horas diárias e de quarenta e quatro para trinta horas semanais. A Comissão de Constituição e Justiça e de Cidadania, em 1996, emitiu parecer unânime admitindo esta proposta com substitutivo. Este substitutivo tem apenas o objetivo de adequar a proposta à técnica legislativa. A PEC no 393, de 2001, de iniciativa do Deputado Inácio Arruda e outros teve por objetivo acrescentar o inciso XIII-A ao artigo $7^{\text {은 }}$ da Constituição federal, de forma a determinar que a jornada semanal seja de quarenta horas a partir de $1^{\circ}$ de janeiro de 2002, e de trinta e cinco horas, a partir de $1^{\circ}$ de janeiro de 2004 . A referida proposta altera, ainda, o inciso XVI do artigo $7^{\circ}$, dispondo que a remuneração do trabalho extraordinário deve ser, no mínimo, de cem por cento superior à da hora normal, e em duzentos por cento aos domingos e feriados. Submetida à apreciação da Comissão de Constituição e Justiça e de Cidadania em 2003, a PEC no 393/2001 teve parecer aprovado por maioria no sentido de admitir a proposta com substitutivo, que retira da Constituição Federal o inciso XIII-A do artigo 7ำ, abrangido pela proposta, sendo que seu teor é compreendido em dispositivo independente que passa a fazer parte de disposição transitória. Estas propostas são antigas e já sofreram arquivamento e desarquivamento. Apesar de possuírem parecer de admissibilidade pela Comissão de Constituição e Justiça e de Cidadania, suas tramitações têm sido complicadas" (ALVES. Rafael César. Redução da jornada de trabalho de 44 para 40 horas semanais: análise à luz da proposta de emenda à constituição 231/1995. ANIMA: Revista Eletrônica do Curso de Direito das Faculdades OPET, ano III, n. 7, 2012, p. 231-232). Cf. tramitação do Projeto de Emenda à Constituição no 231/1995 no site oficial da Câmara dos Deputados. Disponível em: < http://www. camara.gov.br/proposicoesWeb/fichadetramitacao?idProposicao=14582>. Acesso em: 16 abr. 2014.

40 Cf. tramitação do Projeto de Emenda à Constituição no 231/1995 no site oficial da Câmara dos Deputados. Disponível em: <http://www.camara.gov.br/proposicoesWeb/fichadetramitacao?idProposicao=14582>. Acesso em: 16 abr. 2014. 
A Mensagem no 59/2008 foi submetida à apreciação de 3 (três) Comissões Permanentes pela Mesa Diretora da Câmara dos Deputados logo ao início de sua tramitação. ${ }^{41}$ Inicialmente, a proposta de reaplicação da Convenção no $158 / 1982$ da OIT teve dificuldades em sua aprovação pela Comissão de Relações Exteriores e de Defesa Nacional (CREDN), enfrentando a oposição do Deputado Federal Júlio Delgado (PSB/ MG), que emitiu parecer pela sua rejeição. Uma vez revertida a situação na CREDN, o Deputado Federal Sabino Castelo Branco (PTB/AM) emitiu parecer desfavorável à proposta na Comissão de Trabalho, Administração e Serviço Público (CTASP). Os congressistas conseguiram reverter, também nesta comissão, a rejeição da proposta de ratificação. Em seguida, a mensagem foi encaminhada à Comissão de Constituição, Justiça e Cidadania, havendo oposição do parlamentar Arthur Oliveira Maia (PMDB/BA). Nesta última comissão, a proposta ficou estagnada por mais de 2 (dois) anos, tendo ocorrido nova suspensão na tramitação em 15 de abril de 2014 para fins de realização de audiência pública. Desde o início, o trâmite determinado à mensagem foi conturbado, havendo oposições por parte de deputados vinculados à bancada empresária na Câmara dos Deputados. Por estes motivos, a proposta, no sexto ano de sua iniciativa, ainda não se encontra madura para ser votada em Plenário.

Em ambas as controvérsias apresentadas acima, que, nitidamente, afetam interesses empresariais, um congressista ficou reconhecido como "porta-voz" da oposição a estas duas modificações do status quo. À época Deputado Federal e, atualmente, Senador da República, Armando Monteiro Neto protagonizou a atuação da bancada empresarial no Congresso Nacional, combatendo tais propostas. 0 atual Senador, no entanto, não lidera sua categoria unicamente em debates parlamentares. Após o exercício de sucessivos mandatos na Federação da Indústria do Estado de Pernambuco, Armando Monteiro Neto foi eleito Presidente da CNI para exercer o mandato do interregno de 2002 a 2006, sendo reeleito no posto até $2010 .{ }^{42}$ Esta identificação de liderança, nas formas de organização política e de associação

41 Além da mencionada convenção, existem outras tentativas de regulamentar a matéria, sendo, porém, esta digna de maior ênfase no meio acadêmico. Nesse sentido: “A proteção jurídica à relação de emprego contra dispensa imotivada, no plano internacional, foi objeto da Convenção no 158 da OIT. Adotada em 22 de junho de 1982, durante a Conferência Internacional da mencionada organização, teve como antecedentes a Recomendação 119, de 1963, que adotou proposições sobre a terminação da relação de trabalho, e a Convenção $\mathrm{n}^{\circ}$ 142, 1975, que dispunha sobre o desenvolvimento dos recursos humanos, ratificada pelo Brasil em 24 de novembro de 1981. Nessa mesma Conferência, também foi aprovada a Recomendação 166, que trata do término da relação de trabalho por iniciativa do empregador" (ALVARENGA, Rúbia Zanotelli de. Organização Internacional do Trabalho e a Proteção aos Direitos Humanos do Trabalhador, p. 19. Disponível em: <http://www.faculdade.pioxii-es.com.br/img/artigos/artigo_rubia.pdf>. Acesso em: 26 maio 2014). Cf. tramitação da Mensagem no 59/2008 da Presidência da República no site oficial da Câmara dos Deputados. Disponível em: <http://www.camara.gov.br/proposicoesWeb/fichadetramitacao?idProposicao=383867>. Acesso em: 16 abr. 2014.

42 Ressalte-se que no ano de 2008, durante o mandato de Armando Monteiro Neto na CNI, foi julgado o Recurso Extraordinário no 565.714/SP; foi pleiteado e deferido o requerimento de ingresso da CNI na forma de amicus curiae neste mesmo recurso; e foi ajuizada a Rcl no 62.66/DF e concedida a correspondente liminar. 
profissional, comprova o poder da categoria empresarial em se representar para conservar suas conquistas políticas. ${ }^{43}$

A vinculação da base de cálculo do adicional de insalubridade ao salário-mínimo é uma prática proibida nos termos do art. 7ํㅡ, IV, da Constituição Federal. ${ }^{44} \mathrm{~A}$ controvérsia parte do cálculo do adicional - conforme classificada a insalubridade em graus mínimo, médio ou máximo -, na proporção de 10\% (dez por cento), 20\% (vinte por cento) ou 40\% (quarenta por cento) do salário-mínimo. Quanto a estes valores, alguns estudiosos do direito do trabalho com uma percepção mais crítica do sistema econômico vigente indicam que os empregadores são os mais favorecidos. ${ }^{45}$

43 O atual Senador da República não foi o primeiro a presidir a CNI e, simultaneamente, exercer mandato eletivo. Trata-se de uma prática da categoria empresarial que também foi comum na década de 1990: “A situação da CNI começaria a mudar nos anos 1990. As prerrogativas que foram devolvidas ao legislativo pela Constituição de 1988 e o processo de reforma do Estado implementado pelo Presidente da República Fernando Henrique Cardoso, exigiram do empresariado novas estratégias de ação política. Neste contexto, a CNI, ao longo dos anos 1990, especialmente a partir de 1995, utilizou amplamente a arena do Congresso Nacional como um dos principais espaços para exercer influência no processo decisório. Este posicionamento foi intensificado após a escolha de Fernando Bezerra para a presidência da CNI, em outubro de 1995. Empresário da área de construção civil no Rio Grande do Norte, Fernando Bezerra foi eleito Senador da República nas eleições de 1994, participou da Comissão de Assuntos Econômicos do Senado, foi líder do governo e Ministro de Estado da Integração Nacional. A entidade deixaria evidente, desde o primeiro ano das atividades do seu novo presidente, a idéia de parceria e de controle dos encaminhamentos a serem dados pelo governo. Logo em seu discurso de posse, Bezerra salientou que o empresariado estaria atento, utilizando os canais disponíveis [...] Todavia, não há consenso entre as federações, associações patronais e líderes empresariais nacionais com relação à idéia de que a CNI é a entidade do lobby do empresariado industrial. Em 2001, Jorge Gerdau, presidente do Grupo Gerdau e Emílio Odebrecht, presidente do Grupo Odebrecht, Iançaram duras críticas à cúpula da CNI, alegando que era composta em sua maioria por políticos e os interesses dos industriais estariam ficando em segundo plano e, além disso, os recursos seriam utilizados para atender os interesses dos parlamentares que comandam a entidade. Por outro lado, nas últimas eleições para compor a diretoria da entidade, a chapa vencedora sob a presidência de Armando Monteiro Filho, da Federação das Indústrias do Estado de Pernambuco, reforçam a prática tradicional de eleger empresários-políticos do nordeste, derrotando o movimento pela maior representatividade da CNI" (OLIVEIRA, Rosane Cristina de. Empresariado e Congresso Nacional: um estudo das novas estratégias de ação política: a Firjan e a CNI nos anos 90. Dissertação (Mestrado) - UFRJ/IFCS/Programa de Pós-graduação em Ciência Política. 141 fl. Rio de Janeiro: UFRJ/IFCS, 2002. p. 44/68-69, grifos no original. Disponivel em: <http://www.livrosgratis.com.br/arquivos_livros/cp027789.pdf>. Acesso em: 25 abr. 2014).

44 De acordo com a Constituição Federal: “Art. 7ํ São direitos dos trabalhadores urbanos e rurais, além de outros que visem à melhoria de sua condição social: [...] IV - salário mínimo, fixado em lei, nacionalmente unificado, capaz de atender a suas necessidades vitais básicas e às de sua família com moradia, alimentação, educação, saúde, lazer, vestuário, higiene, transporte e previdência social, com reajustes periódicos que Ihe preservem o poder aquisitivo, sendo vedada sua vinculação para qualquer fim; [...]" (sem grifos no original).

45 Como exemplos de autores que, no cenário nacional, apontam esta dificuldade: “Cabe destacar que o objetivo da norma, ao fixar os adicionais de risco, seria de aumentar a remuneração do trabalhador, permitindo o melhoramento da qualidade de vida do obreiro e da sua família, como também de onerar a produção e, pedagogicamente, forçar o empregador a eliminar os elementos nocivos à saúde do trabalhador. Na prática, as empresas, em razão da necessidade de grandes investimentos em tecnologias que reduzam e/ou eliminem as condições de riscos, preferem eternizar o pagamento do adicional de risco em detrimento da segurança, higiene e saúde do trabalhador" (ARAÚJO JúNIOR, Francisco Milton. A monetização do trabalho, antinomia constitucional e a base de cálculo do adicional de insalubridade, p. 4. Disponível em: <http://www. hocupacional.com.br/novo/images/upload/artigos/monetiza\%E7\%E3o\%20do\%20trabalho\%20insalubre.pdf>. Acesso em: 24 mar. 2014). O trecho acima pode ser complementado pelo seguinte: "Contudo, este pretendido caráter pedagógico da medida ao empregador é meramente ilusório, uma vez que não raras vezes estes preferem arcar com o pagamento do adicional de insalubridade, ante a efetivação de medidas que atenuem ou eliminem o risco, pelo alto custo que isto pode representar aos seus cofres, muitas vezes se sobrepondo àquele despendido com o pagamento do acréscimo legal" (CAMPAGNOLI, Adriana de Fátima Pilatti Ferreira; MANDALOZZO, Silvana Souza Netto. Uma (re)leitura do art. 7ํ, XXIII, da Constituição da República - 
O caso chegou ao STF por meio do Recurso Extraordinário № 565.714/SP, interposto por servidores públicos do Estado de São Paulo, versando sobre a Lei Complementar Estadual o 432/1985. ${ }^{46}$ Os autores indicavam o art. 7ํㅡ, IV, da Constituição, como um impedimento à base de cálculo prevista na legislação estadual, oferecendo a remuneração do servidor, termo empregado pelo art. 7ํㅡ, XXIII, da Constituição, como alternativa. Até então, o recurso parecia versar somente sobre questão relacionada a servidores públicos do Estado de São Paulo, mas a Ministra Cármen Lúcia, relatora do processo, deferiu o ingresso da CNI como amicus curiae por entender que havia pertinência temática. Com isso, as discussões foram expandidas para abranger também a inconstitucionalidade da base de cálculo do adicional de insalubridade de natureza celetista.

No julgamento, ficou estabelecida a não recepção do art. 3o da Lei Complementar Estadual no 432/1985, ressaltando que o fim da base de cálculo não implica extinção do adicional legalmente previsto. A Corte limitou-se a declarar a não recepção desta prática, mas sustentou que a base de cálculo somente poderia ser substituída por lei ou norma coletiva. Após o julgamento deste precedente, foi aprovada a Súmula Vinculante no $4 .{ }^{47}$ O TST, em resposta, promoveu uma reedição de seu verbete de número 228, estabelecendo o seguinte: “[...] o adicional de insalubridade será calculado sobre o salário básico, salvo critério mais vantajoso fixado em instrumento coletivo". ${ }^{48}$ A modificação beneficiou os empregados que fizessem jus ao adicional, pois sua base de cálculo foi elevada do salário-mínimo nacional para o salário básico do empregado. Este enunciado buscava preencher o vazio legislativo

possíveis alternativas para a monetização do risco com enfoque em atividades insalubres. In: NASCIMENTO, Grasiele Augusta Ferreira; MISAILIDIS, Mirta Gladys Lerena Manzo de; BACARAT, Eduardo Milléo (Coord.). Direito do Trabalho - XXII Encontro Nacional do CONPEDI. Florianópolis: FUNJAB, 2013, p. 280). Entre outros, Cf. DARONCHO, Leomar. Adicional de insalubridade: entre a monetização da saúde do trabalhador e o direito fundamental ao meio ambiente de trabalho hígido. Rio de Janeiro: FIOCRUZ, 2012. Disponível em: <http:// aplicacao.tst.jus.br/dspace/bitstream/handle/1939/25601/2012_daroncho_leomar.pdf?sequence=1>. Acesso em: 24 mar. 2014.

46 A lei impugnada, em seu art. 3o, dispõe que tais servidores farão jus ao adicional de insalubridade, adotando a mesma classificação e o mesmo percentual que a CLT, dobrando, no entanto, sua base de cálculo. Eliminando qualquer sombra de dúvida, o parágrafo primeiro deste dispositivo legal tornou a referência a 2 (dois) saláriosmínimos um fator de indexação ao estabelecer seu reajuste automático. Os autores da ação pleiteavam a substituição da base de cálculo do adicional previsto pela Lei Estadual pelo total da remuneração do servidor que lhe fizesse jus.

47 De acordo com a Súmula Vinculante no 4 de 2008: “salvo nos casos previstos na constituição, o salário mínimo não pode ser usado como indexador de base de cálculo de vantagem de servidor público ou de empregado, nem ser substituído por decisão judicial."

48 De acordo com a Súmula no 228 do TST: “ADICIONAL DE INSALUBRIDADE. BASE DE CÁLCULO (redação alterada na sessão do Tribunal Pleno em 26.06.2008) - Res. 148/2008, DJ 04 e 07.07.2008 - Republicada DJ 08, 09 e 10.07.2008. SÚMULA CUJA EFICÁCIA ESTÁ SUSPENSA POR DECISÃO LIMINAR DO SUPREMO TRIBUNAL FEDERAL - Res. 185/2012, DEJT divulgado em 25, 26 e 27.09.2012. A partir de 9 de maio de 2008, data da publicação da Súmula Vinculante no 4 do Supremo Tribunal Federal, o adicional de insalubridade será calculado sobre o salário básico, salvo critério mais vantajoso fixado em instrumento coletivo" (Disponível em: <http://www3.tst.jus.br/jurisprudencia/Sumulas_com_indice/Sumulas_Ind_201_250.html\#SUM-228>. Acesso em: 19 mar. 2014). 
através da interpretação, fazendo cessar uma inconstitucionalidade observada com recorrência na prática trabalhista - algo de que o próprio STF se absteve. Com a tentativa do TST de uniformizar a jurisprudência sobre o tema, algumas Reclamações Constitucionais foram direcionadas ao STF. ${ }^{49} \mathrm{~A} \mathrm{Rcl} \mathrm{no} \mathrm{6.266/DF,} \mathrm{ajuizada} \mathrm{pela} \mathrm{CNI}$ e primeira tentativa de anular a Súmula no 228 do TST apresentada ao STF, até o presente momento não foi julgada em definitivo, havendo unicamente uma decisão proferida em caráter liminar. A decisão tomada pelo Presidente acolheu o argumento da CNI de que havia urgência em seu julgamento. Desse modo, a súmula do TST, cuja reedição foi publicada em 10 de junho de 2008, teve sua eficácia suspensa pela medida liminar da Presidência do STF após 5 (cinco) dias de vigência. ${ }^{50} 0$ julgamento definitivo da Reclamação, entretanto, não foi observado até o presente momento. ${ }^{51}$

Nesta controvérsia, a participação da CNI pode ser facilmente constatada devido ao deferimento de sua participação como amicus curiae. ${ }^{52}$ Porém, muito mais importante é perceber o comportamento que tem sido apresentado por representantes

49 A primeira das Reclamações ajuizadas no STF e que, portanto, tornou preventa a relatoria da Ministra Cármen Lúcia para esta temática foi a Rcl no 6.266/DF, de iniciativa da CNI, mesma entidade que participou do RE no 565.714/SP como amicus curiae. Em seguida, as Rcl no 6.275/SP, no 6.277/SP e n 8.436/SP também tiveram o mesmo tempo como objeto, sendo apensadas àquela ajuizada pela CNI.

50 A Resolução Administrativa do TST no 148/2008 foi o instrumento utilizado pelo Tribunal para reeditar a Súmula no 228 . Sua publicação ocorreu em 7 de julho de 2008 , mas republicações também se observaram nos três dias seguintes.

51 Uma recente decisão foi tomada pelo STF nos autos da Rcl no 13.860/SC. Esta Reclamação, ao contrário das demais, foi rapidamente apreciada pela Ministra Rosa Weber, relatora. Tentou-se impugnar uma decisão do TST que aplicou o salário-mínimo como base de cálculo do adicional de insalubridade, alegando-se que o salário base da categoria deveria substituí-lo. Em mais uma oportunidade, o STF manifestou o sedimentado entendimento de que a inconstitucionalidade deveria ser mantida até que houvesse lei ou norma coletiva dedicada ao assunto.

52 O amicus curiae, termo latino referente a "amigo da corte", é um instituto jurídico que, embora seja muito tratado pela doutrina e recorrido na prática jurisdicional, não possui uma regulamentação legal específica. O STF costuma aplicar a seus requerimentos disposições genéricas de seu Regimento Interno que versam sobre "manifestações de terceiros". De acordo com o Regimento Interno do STF: "Art. 13. São atribuições do Presidente: [...] XVIII - decidir, de forma irrecorrível, sobre a manifestação de terceiros, subscrita por procurador habilitado, em audiências públicas ou em qualquer processo em curso no âmbito da Presidência [...] Art. 21. São atribuições do Relator: [...] XVIII ${ }^{1}$ - decidir, de forma irrecorrivel, sobre a manifestação de terceiros, subscrita por procurador habilitado, em audiências públicas ou nos processos de sua relatoria. [...]". A teoria constitucional norte-americana, durante o século XX, observou o surgimento de relevantes pesquisas indicando que o tradicional instrumento em que um terceiro contribuía com a Corte, em sua tarefa de perseguir a verdade e aplicar o direito de forma justa ao caso concreto, estaria sendo utilizado, em inúmeros casos, para finalidade diversa. Muitos amicus briefs estariam sendo oferecidos com o objetivo de defender o interesse de uma das partes do processo e, com isso, foi instaurada uma discussão acerca do litigating amicus, questionando se tais terceiros estranhos ao processo seriam amigos da Corte ou amigos da parte. Cf. KRISLOV, Samuel. The Amicus Curiae Brief: from Friendship to Advocacy. Yale Law Journal, v. 72, 694, 1962-193; LOWMAN, Michael. The Litigating Amicus Curiae: when does the party begin after the friends leave. The American University Law Review, v. 41, 1243, 1992. A figura do litigating amicus tende a ser comum quando há pouca regulamentação para o exercício dessa forma de manifestação e, tendo em vista o tratamento normativo precário existente no Brasil, a presença do "amigo da parte" não é algo estranho à realidade brasileira. A própria controvérsia selecionada na presente pesquisa apresenta a CNI ingressando no Recurso Extraordinário no 565.714/SP, tendo, nitidamente, interesses econômicos diretamente dependentes do precedente que seria formado. $\mathrm{O}$ fato de a CNI ter ajuizado uma reclamação constitucional no STF comprova este interesse econômico direto. Para aprofundar o debate sobre "amigo da Corte" ou “amigo da parte" no cenário brasileiro, Cf. MEDINA, Damares. Amicus curiae - amigo da corte ou amigo da parte?. São Paulo: Saraiva, 2010. 
do empresariado no Congresso Nacional, sob a forma da bancada suprapartidária, no sentido de impedir a aprovação de projetos legislativos contrários aos interesses da categoria, asseverando sua condição de veto player. A capacidade de organização da categoria deve ser ressaltada, neste momento, devido ao sucesso dos empresários em, pela CNI no Recurso Extraordinário no 565.714/SP, exigir que a mudança do status quo ocorresse por lei para, então, impedir que qualquer projeto de lei pudesse ser aprovado através da bancada empresarial. No total, entre 1988 e 2014, foram iniciados 34 (trinta e quatro) projetos de lei com o objetivo de alterar a base de cálculo do adicional de insalubridade. Nenhuma das propostas vingou até o momento, já tendo sido 15 (quinze) - 44\% (quarenta e quatro por cento) aproximadamente - delas derrotadas pelos parlamentares que representam os interesses empresariais. Os projetos que ainda não foram arquivados tramitam conjuntamente ao Projeto de Lei da Câmara (PLC) ํo 2.549/1992, pronto para deliberação em Plenário desde 2009, mas nunca inserido na Ordem do Dia. ${ }^{53}$

Os três casos emblemáticos apresentados acima não representam situações isoladas e excepcionais do sistema político e institucional brasileiro. Ao contrário, por terem concentrado maior atenção do público envolvido e repercutido mais significativamente na atividade dos parlamentares e do Judiciário, parecem ilustrar mais diretamente o fenômeno inicialmente apontado da distorção majoritária. Estes, porém, não são os únicos exemplos aptos a demonstrar a influência da bancada empresarial no Congresso Nacional. Outras controvérsias também representam o comportamento predominantemente conservador desta organização e, embora não tenham gerado a mesma repercussão que as mencionadas acima, são de profunda relevância: (i) a impossibilidade de punição do crime de retenção dolosa do salário, devido à inexistência de lei; (ii) a alteração da base de cálculo do adicional de periculosidade de eletricitários promovida por lei, porém, reduzindo o valor percebido; (iii) a não instituição, cobrança e fiscalização do Imposto

\footnotetext{
53 Na Câmara dos Deputados, tramitam conjuntamente ao PLC no 2.549/1992 os seguintes: PLCs no 1.165/1988, no 391/1991, no 522/1999, no 5.290/2001, no 3.784/20008, no 4.133/2008, no 532/2011, ํo 1.540/2011 e ํo 1.881/2011. Destaque-se que o PLC no 6.868/2013 está apensado ao de no 1.881/2011, por sua vez, apensado ao PLC no 2.549/1992; que o PLC no 6.994/2010 está apensado ao de no 391/1991; que os PLCs no 5.666/2009, no 5.067/2009, no 4.770/2009 estão apensados ao de no 1.165/1988; e que o PLC no 3.900/2008 está apensado ao de no 3.784/2008. No Senado Federal, tramitam conjuntamente ao PLC no 2.549/1992 os seguintes: PLS no 332/1991, no 294/2008 e no 484/2008, estando os dois últimos pendentes de parecer Comissão de Constituição, Justiça e Cidadania do Senado Federal. No total, correm conjuntamente com este PLC outros 18 (dezoito) projetos - 15 (quinze) da Câmara dos Deputados e 3 (três) do Senado Federal. Considerando-se que, em um universo de 34 (trinta e quatro) propostas, 15 (quinze) constam como arquivados, e 18 (dezoito) estão direta ou indiretamente apensados ao $\mathrm{PL}$ no 2.549/1992, todos os projetos de lei ativos na matéria tramitam conjuntamente. Cf. informações no sítio oficial da Câmara dos Deputados. Disponível em: <http://www2.camara.leg.br/>. Acesso em: 24 abr. 2014.
} 
sobre Grandes Fortunas (IGF); e (iv) o sistema penal de prevenção e repressão de crimes tributários. ${ }^{54}$

$\mathrm{O}$ artigo $7^{\circ}$, X, da Constituição Federal, determina a "proteção do salário na forma da lei, constituindo crime sua retenção dolosa”. ${ }^{55}$ A relevância penal desta prática decorre da própria Constituição, que define em que esfera será punida a conduta. Porém, é um princípio penal inafastável a legalidade, sendo necessária a aprovação de lei definindo o tipo penal que combateria esta prática e estabelecendo sua respectiva pena. A arguição da prática de retenção dolosa do salário é comum nos tribunais, mas, em geral, os trabalhadores só podem contar com medidas indenizatórias ou, no máximo, com a aplicação de sanções administrativas. Em primeiro lugar, mesmo com a determinação constitucional de punir criminalmente tal conduta, até então, nenhuma lei foi aprovada para esta finalidade, impossibilitando a tutela penal deste bem jurídico relevante de natureza alimentar - o salário. Em segundo lugar, como contrapartida à inexistência de lei descrevendo o crime de retenção dolosa do salário, há algumas tentativas de coibir esta prática na jurisprudência, podendo-se destacar: (a) a tentativa de imputação do crime de apropriação indébita (art. 168, Código Penal); (b) a aplicação do Decreto-Lei no 368/1968, que dispõe sobre os efeitos da mora salarial; (c) o reconhecimento da rescisão indireta do

54 Quanto aos exemplos ora mencionados, é importante destacar que nem todos ilustram, especificamente, o comportamento conservador da bancada empresarial - por isso, foi empregado o termo "predominantemente" como seu qualificante. Em geral, o comportamento - e, pode-se afirmar, a função precípua - da bancada empresarial se caracteriza como a tentativa de conservar as conquistas políticas da categoria. Em determinadas hipóteses, o comportamento pode ser diverso, mas, mesmo nestas circunstâncias, o exercício do poder de veto da bancada empresarial resta confirmado. Entre os casos acima enumerados, o primeiro e o terceiro - retenção dolosa de salário e instituição do IGF - são exemplos claros de comportamento conservador. O segundo caso, no entanto - adicional de periculosidade dos eletricitários -, expressa, mais propriamente, um exemplo de comportamento restaurador, pois se retornou a um status quo ante em detrimento de avanços em matéria de direitos trabalhistas. Por fim, o último caso - sistema de prevenção e repressão de crimes tributários - não indica um comportamento conservador ou restaurador. A partir da lógica do poder de agenda, é preciso considerar que propostas altamente convenientes à bancada empresarial foram oferecidas pelo Poder Executivo. Com isso, houve uma alteração incremental do status quo legislativo, autorizada por este veto player. As mudanças incrementais são analisadas por Tsebelis em passagens como as seguintes: "Even without transaction costs, if players undertake a change, a small winset of the status quo [conjunto de propostas que podem modificar o status quo] means that the change will be incremental. In other words, a small winset of the status quo precludes major policy changes. [...] Another way of thinking about this situation is that the more divided each one of the two chambers is, the more possibilities are presented to the president to achieve agreement on some particular alternative. In fact, if the two chambers are politically very close to each other, incremental change may always be possible. [...] Single-party governments will have all discretion in changing the status quo, while multiparty governments will make only incremental changes" (TSEBELIS, George. Veto Players: How Political Institutions Work. Princeton, NJ: Princeton University Press, 2002. p. 22/50/91). Modificações incrementais indicam que as mudanças foram de reduzido impacto, não provocando grandes subversões no sistema político e não contrariando as preferências dos atores presentes.

55 De acordo com a Constituição Federal: “Art. 7ํㅗ̃o direitos dos trabalhadores urbanos e rurais, além de outros que visem à melhoria de sua condição social: [...] X - proteção do salário na forma da lei, constituindo crime sua retenção dolosa; [...]". 
contrato de trabalho pelo empregador; e (d) a indenização por dano moral decorrente de retenção salarial. ${ }^{56}$

A primeira destas medidas - apropriação indébita - não é aceita pela jurisprudência, alegando-se a não ocorrência da inversão do justo título da posse do salário e a impossibilidade de aplicação da analogia in malam partem no direito penal. ${ }^{57} \mathrm{~A}$ segunda medida - Decreto-Lei no 368/1968 - é interpretada pelo Judiciário como um parâmetro de ordem administrativa e fiscal, sem aplicabilidade em termos de direito subjetivo. ${ }^{58} \mathrm{O}$ diploma legal é abordado com frequência na jurisprudência, mas para fins de definição de mora salarial. Seu uso para fins sancionatórios, no entanto, é significativamente contido e, em muitos casos, somente é aplicada se comprovada a mora contumaz - atraso superior ou equivalente a 3 (três) meses. ${ }^{59}$ A terceira medida - reconhecimento da rescisão indireta - é uma das formas mais aceitas pela jurisprudência, mas não representa um verdadeiro meio de proteção do trabalhador. A retenção salarial é tratada como falta grave e enseja ajuizamento de ação própria a rescindir indiretamente o contrato. No entanto, o empregado perde sua renda mensal em troca das indenizações que receberia caso estivesse sendo demitido. ${ }^{60} \mathrm{~A}$

56 Uma pesquisa aprofundada da temática da retenção dolosa de salário e as respectivas medidas reconhecidas pela jurisprudência visando combater a mora salarial pode ser encontrada em LEÃO, Priscila Muñoz. Proteção Jurídica do Salário e o Artigo 7, Inciso X da CRFB. 2013. 66 f. Monografia (Graduação em Direito) - Universidade Federal do Rio de Janeiro, Rio de Janeiro, 2013. A abordagem das medidas alternativas apresentada a seguir se baseia nesta referência em particular.

57 O precedente paradigma na matéria foi proferido pelo Superior Tribunal de Justiça: “HABEAS CORPUS. [...] APROPRIAÇÃO INDÉBITA. RETENÇÃO DE SALÁRIOS PELO EMPREGADOR. ATIPICIDADE RECONHECIDA. TRANCAMENTO DA AÇÃO PENAL ACOLHIDO. [...] 2. A retenção dolosa de salário, conquanto tenha sido prevista no art. $7^{\circ}, \mathrm{X}$ da Constituição Federal como crime, ainda ressente-se da necessária lei, criando o tipo penal respectivo. 3. Também não há como subsumir a conduta à apropriação indébita (art. 168 do Código Penal), porque o numerário ao qual o empregado tem direito, até que lhe seja entregue, em espécie ou por depósito, é de propriedade da empresa (empregador), não havendo se falar, então, em inversão da posse, necessária para a tipicidade do crime. 4. 0 administrador da empresa, ao assim agir, não pratica fato típico previsto no art. 168 do Código Penal. Talvez por isso tenha o legislador constituinte feito a previsão mencionada, mas ainda sem eficácia, ante a omissão legislativa. [...]" (HC no 201001183666, STJ, Sexta Turma, Min. Rel. Maria Thereza de Assis Moura, DJE, 26 ago. 2013).

58 Entre as sanções previstas pelo Decreto-Lei nํ 368/1968: “Art. 1ํ․ A empresa em débito salarial com seus empregados não poderá: I - pagar honorário, gratificação, pro labore ou qualquer outro tipo de retribuição ou retirada a seus diretores, sócios, gerentes ou titulares da firma individual; II - distribuir quaisquer lucros, bonificações, dividendos ou interesses a seus sócios, titulares, acionistas ou membros de órgãos dirigentes, fiscais ou consultivos; III - ser dissolvida."

59 Como exemplo da jurisprudência que exige comprovação da mora contumaz para aplicação dos efeitos do Decreto-Lei no 368/1968: “RESCISÃO INDIRETA DO CONTRATO DE TRABALHO. FALTA GRAVE DO EMPREGADOR. NÃO CONFIGURADA. In casu, o atraso no pagamento de salários em média de 30 dias a 60 dias, não configura falta grave do empregador a respaldar pretensa rescisão indireta do contrato de trabalho pela aplicação do art. 483, 'd' da CLT, porquanto nos termos do Decreto-lei 368/68, art. 2ำ §1ํㅡ, a mora salarial não está configurada. Recurso Ordinário patronal parcialmente provido" (RO ํo 753200601406009, TRT-6, Terceira Turma, Des. Rel. Gilvan de Sá Barreto, DJE, 15 nov. 2007).

60 Como exemplo da aplicação da rescisão indireta nos casos de retenção salarial: "RESCISÃO INDIRETA. ATRASO NO PAGAMENTO DOS SALÁRIOS E AUSÊNCIA DE RECOLHIMENTO DO FGTS DURANTE O PACTO LABORAL. O descumprimento de obrigações contratuais pelo empregador tais como o atraso no pagamento de salários e o recolhimento dos depósitos de FGTS, configura falta grave. Tal situação, nos termos do artigo 483, alínea d, da CLT, autoriza o rompimento indireto do vínculo empregatício e a consequente condenação da empregadora ao pagamento das verbas rescisórias. Recurso não conhecido" (RR no 1057006220095120010, TST, Segunda Turma, Min. Rel. José Roberto Freire Pimenta, Segunda Turma, DEJT, 13 set. 2013). 
quarta medida - indenização por dano moral - não é aplicada de modo uniforme pela jurisprudência, sendo comum a ocorrência de condenações tímidas. Em geral, prevalece o entendimento de que o inadimplemento per se não configura dano moral, devendo este ser comprovado de modo inequívoco. ${ }^{61} \mathrm{~A}$ matéria se encontra, atualmente, tão controversa que um mesmo órgão fracionário do TST, responsável por uniformizar a jurisprudência trabalhista, constrói precedentes contemporâneos antagônicos. ${ }^{62}$

O histórico de percepção do adicional de periculosidade para eletricitários demonstra outro sucesso da bancada empresarial em sua defesa aos interesses econômicos da categoria. Neste caso, em particular, seu comportamento não pode ser caracterizado propriamente como conservador, impedindo que alterações se promovessem em face do status quo. Ao contrário, a mudança possui caráter restaurador, pois conduziu a regulamentação legal da profissão a um retrocesso em termos de direitos trabalhistas. Até a publicação da Lei no $12.740 / 2012$, os profissionais expostos à energia elétrica em condições de periculosidade faziam jus à percepção do adicional correspondente calculado sobre 30\% (trinta por cento) do salário efetivamente recebido pelo empregado. ${ }^{63}$ Esta era uma garantia legal de caráter compensatório vigente deste o ano de 1985, havendo, inclusive, jurisprudência sumulada do TST garantindo-Ihe efetividade. ${ }^{64}$ Recentemente, no entanto, o Congresso Nacional restaurou o status quo ante ao aprovar a Lei no 12.740. Este novo diploma legal revogou expressamente a regulamentação anterior sobre a matéria. ${ }^{65}$

61 Ilustrando este entendimento, é possivel conferir a ementa a seguir proferida pelo Regional do Rio de Janeiro: "MORA SALARIAL - DANO MORAL - NÃO CONFIGURAÇÃO. O atraso reiterado no pagamento dos salários, embora possa causar desequilíbrio no orçamento do autor, resulta em lesão exclusivamente patrimonial, não configurando abalo à honra ou imagem do empregado" (RO № 1539001720095010072, TRT-1, Primeira Turma, Des. Rel. Mery Bucker Caminha, DJE 2012-08-10.

62 Demonstrando a incompatibilidade dos precedentes contemporâneos do TST, podem ser mencionadas as seguintes decisões, respectivamente, aplicando o dano moral decorrente de retenção salarial e não o aplicando: “RECURSO DE REVISTA 1 - DANOS MORAIS. ATRASO NO PAGAMENTO DE SALÁRIOS. Hipótese em que o Tribunal Regional reconheceu ter sido incontroversa a reiteração do atraso no pagamento dos salários, o que dá ensejo à indenização por danos morais, cujo objetivo é o de diminuir ou compensar o constrangimento pelo fato de a empregada ver-se privada, ainda que temporariamente, dos recursos necessários à sua subsistência. Recurso de revista não conhecido. [...]" (RR no 546007220095040016, TST, Sétima Turma, Min. Rel. Delaíde Miranda Arantes, DEJT, 16 ago. 2013). “RECURSO DE REVISTA - DANOS MORAIS - SIMPLES ATRASO NO PAGAMENTO DOS SALÁRIOS - NÃO CONFIGURAÇÃO. O simples atraso no pagamento dos salários não dá ensejo à condenação em danos morais. A indenização por danos morais justifica-se nos casos em que há patente violação de direitos personalíssimos do trabalhador, no curso da relação empregatícia ou dela decorrente. Ressalte-se que somente fica configurando dano à esfera extrapatrimonial do empregado quando a mora salarial é reiterada ou tenha ocasionado outros fatos objetivos mais graves e contundentes, o que não está evidente no caso. Recurso de revista não conhecido" (RR no 15381120115090016, TST, Sétima Turma, Min. Rel. Luiz Philippe Vieira de Mello Filho, DEJT, 04 out. 2013).

63 De acordo com a Lei ํㅜ 7.369/1985 (revogada): “Art. 1ํㅇ empregado que exerce atividade no setor de energia elétrica, em condições de periculosidade, tem direito a uma remuneração adicional de trinta por cento sobre o salário que perceber."

64 De acordo com o Enunciado de Súmula no 191 do TST: “Adicional de Periculosidade - Incidência. O adicional de periculosidade incide apenas sobre o salário básico e não sobre este acrescido de outros adicionais. Em relação aos eletricitários, o cálculo do adicional de periculosidade deverá ser efetuado sobre a totalidade das parcelas de natureza salarial" (sem grifos no original).

65 De acordo com a Lei oㅜ 12.740/2012: “Art. oㅜ Fica revogada a Lei no 7.369, de 20 de setembro de 1985." 
Com isso, a matéria deixou de contar com regulamentação em lei específica, passando a CLT a representar o parâmetro jurídico para sua percepção e seu cálculo, nos termos do art. $193 .{ }^{66}$ A CLT, que não mencionava a condição jurídica dos eletricitários em matéria de adicional de periculosidade, equiparou-a aos demais casos de exposição a materiais inflamáveis e explosivos, ou a circunstâncias de roubo ou de violência física, cuja base de cálculo é mais reduzida do que a prevista na lei revogada - agora 30\% (trinta por cento) incidente sobre o salário básico. ${ }^{67}$ Este exemplo demonstra que a capacidade de organização da bancada empresarial não se limita a conquistas políticas conservativas, também sendo o grupo capaz de restaurar condições mais convenientes, causando retrocesso à proteção de direitos em matéria trabalhista.

A Constituição prevê, em seus arts. 153, 155 e 156, os impostos cuja instituição compete, respectivamente, à União, aos Estados e ao Distrito Federal e aos Municípios. Entre os impostos definidos pela Constituição como de competência da União para sua instituição, há o Imposto sobre Grandes Fortunas (IGF). ${ }^{68}$ Há duas excepcionalidades associadas ao IGF de suma relevância, sobretudo para os propósitos do presente trabalho: (a) trata-se do único imposto cuja instituição depende de lei complementar, uma exceção à exigência constitucional de lei ordinária para os demais, e (b), complementando este fato, trata-se do único imposto constitucionalmente previsto que, após mais de 25 (vinte e cinco) anos, ainda não foi instituído. ${ }^{69}$

66 De acordo com a CLT, conforme redação alterada pela Lei no 12.740/2012: “Art. 193. São consideradas atividades ou operações perigosas, na forma da regulamentação aprovada pelo Ministério do Trabalho e Emprego, aquelas que, por sua natureza ou métodos de trabalho, impliquem risco acentuado em virtude de exposição permanente do trabalhador a: I - inflamáveis, explosivos ou energia elétrica; II - roubos ou outras espécies de violência física nas atividades profissionais de segurança pessoal ou patrimonial. [...]".

67 De acordo com a CLT: “Art. 193. São consideradas atividades ou operações perigosas, na forma da regulamentação aprovada pelo Ministério do Trabalho e Emprego, aquelas que, por sua natureza ou métodos de trabalho, impliquem risco acentuado em virtude de exposição permanente do trabalhador a: I - inflamáveis, explosivos ou energia elétrica; II - roubos ou outras espécies de violência física nas atividades profissionais de segurança pessoal ou patrimonial. $\S 1^{\circ}$ - 0 trabalho em condições de periculosidade assegura ao empregado um adicional de $30 \%$ (trinta por cento) sobre o salário sem os acréscimos resultantes de gratificações, prêmios ou participações nos lucros da empresa. [...]" (sem grifos no original).

68 De acordo com a Constituição Federal: “Art. 153. Compete à União instituir impostos sobre: I - importação de produtos estrangeiros; II - exportação, para o exterior, de produtos nacionais ou nacionalizados; III - renda e proventos de qualquer natureza; IV - produtos industrializados; V - operações de crédito, câmbio e seguro, ou relativas a títulos ou valores mobiliários; VI - propriedade territorial rural; VII - grandes fortunas, nos termos de lei complementar. [...]" (sem grifos no original).

69 A assertiva de que "nenhum imposto da União além do IGF exige lei complementar para sua instituição" requer um esclarecimento de ordem terminológica: o que se considera imposto para os propósitos do presente trabalho? A doutrina especializada se divide em alguns posicionamentos dignos de ênfase quando distinguem a natureza jurídica das espécies de tributos. Entre as teorias bipartite, tripartite, quadripartite e pentapartite, esta última precisamente parece ser a mais adequada para sustentar a afirmativa. De acordo com esse entendimento, os tributos podem ser classificados como impostos, taxas, contribuições de melhoria - formais tradicionais previstas no Código Tributário Nacional -, além dos empréstimos compulsórios e das contribuições especiais. Este tem sido o entendimento pacífico mantido pelo STF em precedentes como o seguinte: "CONSTITUCIONAL. TRIBUTÁRIO. CONTRIBUIÇÕES SOCIAIS. [...] II. - A contribuição da Lei 7.689, de 15.12.88, e uma contribuição social instituída com base no art. 195, I, da Constituição. As contribuições do art. 195, I, II, III, da Constituição, não exigem, para a sua instituição, lei complementar. Apenas a contribuição do parag. 4. do mesmo art. 195 
O Sistema Tributário Nacional, além das disposições constitucionais, atende a regramentos previstos pela Lei Complementar nº 101/2000 - também conhecida como Lei de Responsabilidade Fiscal (LRF). Nos termos desta lei complementar, os entes federativos detêm responsabilidades financeiras e, assim, possuem o dever de instituir os impostos de sua competência, estimar a receita que deverá ser arrecadada no exercício fiscal e, ainda, proceder à efetiva arrecadação destes tributos. ${ }^{70} \mathrm{O}$ ente federativo que não observa tais disposições essenciais à gestão fiscal fica sujeito à sanção prevista no parágrafo único do art. 11 da LRF. Esta sanção, entretanto, foi concebida como um mecanismo em defesa da União, pois a administração de muitos Municípios depende das transferências de receita que recebem dos Estados e da União, provenientes da arrecadação de seus respectivos tributos na forma da repartição constitucional - arts. 157 a 162 da Constituição Federal. A União é o único ente federativo que não se encontra sujeito às sanções do parágrafo único do art. 11 da LRF, pois não recebe transferências de receita corrente de nenhum ente federativo por repartição constitucional. ${ }^{71}$ Deste modo, a não instituição do IGF pela União, único imposto que requer lei complementar, e não lei ordinária, e que ainda não foi instituído, embora constitucionalmente previsto, não observa sanções no plano da responsabilidade fiscal, fato este que pode ser diretamente relacionado à atuação da bancada empresarial no Congresso Nacional na defesa dos interesses econômicos desta categoria. ${ }^{72}$

e que exige, para a sua instituição, lei complementar, dado que essa instituição devera observar a técnica da competência residual da União (C.F., art. 195, parag. 4.; C.F., art. 154, I). Posto estarem sujeitas a lei complementar do art. 146, III, da Constituição, porque não são impostos, não há necessidade de que a lei complementar defina o seu fato gerador, base de calculo e contribuintes (C.F., art. 146, III, "a"). [...]" (RE no 138.284/CE, STF, Plenário, Min. Rel. Carlos Velloso, DJ, 28 ago. 1992). A importância do apontamento acima decorre do fato de que empréstimos compulsórios e certas contribuições especiais exigem lei complementar para sua instituição, devendo-se distinguir tais espécies dos impostos previstos taxativamente no art. 153 da Constituição Federal com base na teoria pentapartite a que se associa o STF.

70 De acordo com a Lei de Responsabilidade Fiscal: “Art. 11. Constituem requisitos essenciais da responsabilidade na gestão fiscal a instituição, previsão e efetiva arrecadação de todos os tributos da competência constitucional do ente da Federação. Parágrafo único. É vedada a realização de transferências voluntárias para o ente que não observe o disposto no caput, no que se refere aos impostos" (sem grifos no original).

71 A única previsão constitucional de transferência de arrecadação de imposto instituído pelos Estados, Distrito Federal ou Municípios à União não é propriamente uma regra de repartição de receita constitucional. Trata-se de uma exceção ao princípio da não afetação da receita pública, em que se prestam garantias ou contragarantias à União ou se pagam débitos contraídos perante este ente federativo, previsto no art. 167 da Constituição Federal: “Art. 167. São vedados: [...] IV - a vinculação de receita de impostos a órgão, fundo ou despesa, ressalvadas a repartição do produto da arrecadação dos impostos a que se referem os arts. 158 e 159 , a destinação de recursos para as ações e serviços públicos de saúde, para manutenção e desenvolvimento do ensino e para realização de atividades da administração tributária, como determinado, respectivamente, pelos arts. $198, \S^{\circ} 2^{\circ}, 212$ e 37, XXII, e a prestação de garantias às operações de crédito por antecipação de

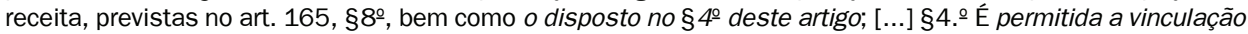
de receitas próprias geradas pelos impostos a que se referem os arts. 155 e 156, e dos recursos de que tratam os arts. 157, 158 e 159, I, a e b, e II, para a prestação de garantia ou contragarantia à União e para pagamento de débitos para com esta" (sem grifos no original).

72 Talvez, o único meio viável de se responsabilizar a União pela não instituição do IGF na forma da LRF seria aplicar uma interpretação com caráter extensivo, arguindo que as transferências do art. 167, §4ํㅡ, da Constituição Federal, fazem parte do sistema de repartição constitucional de receita pública ou, simplesmente, devem ser abrangidos, por sua natureza, pelas sanções estipuladas pelo art. 11, parágrafo único, da LRF, tornando inexigivel o crédito da União enquanto tal imposto não for instituído. Embora seja difícil cogitar o Judiciário intervindo tão incisivamente em matéria financeira e orçamentária, esperar uma reforma normativa não parece ser a medida mais provável diante do comportamento conservador da bancada empresarial. 
Uma dimensão da legislação brasileira que se apresenta profundamente favorável à categoria empresarial é a flexibilização da persecução penal em crimes de natureza tributária. Para os propósitos deste trabalho, tal flexibilidade será apresentada segundo 3 (três) aspectos: (a) a suspensão da exigibilidade do crédito tributário decorrente da adesão a regimes de parcelamento; (b) a extinção da exigibilidade do crédito tributário decorrente de sua quitação; e (c) a aplicação do princípio da insignificância em crimes tributários.

Quanto aos dois primeiros aspectos, desde o ano de 2000, diversos regimes de parcelamento do crédito tributário criados especialmente para beneficiar a condição fiscal de pessoas jurídicas foram criados, podendo-se destacar o Refis, o Paes, o Paex, o Refis da Crise, o Simples Nacional, entre outros regimes inominados legalmente previstos. ${ }^{73}$ A partir de tais regimes, foram criadas disposições legais concernentes à suspensão e à extinção da exigibilidade do crédito tributário, o que conduz, consequentemente, à suspensão da pretensão punitiva do Estado e à extinção da punibilidade dos respectivos crimes tributários. ${ }^{74} \mathrm{Em}$ primeiro lugar,

73 O Programa de Recuperação Fiscal (Refis) foi instituído pela Lei no 9.964/2000 e alterado em diversas oportunidades para fins de prorrogação de seu prazo de validade - a exemplo da Lei no 10.002/2000 - ou de ampliação de seu escopo - a exemplo da Lei no 10.637/2002, que, entre outras providências, integrou débitos do Programa de Integração Social e de Formação do Patrimônio do Servidor Público (PIS/Pasep) ao Refis. O Programa de Parcelamento Especial (Paes) foi instituído pela Lei no 10.684/2003 e o Programa de Parcelamento Extraordinário (Paex) pela Medida Provisória no 303/2006, já exauridos seus efeitos. O Refis foi reformulado após a crise financeira e imobiliária de 2008. Com isso, a instituição do novo regime de parcelamento - que se difundiu como "Refis da Crise" -, instituído pela Lei no 11.941/2009, permitiu que as empresas anteriormente aderidas a outros regimes legais de parcelamento tributário a ele aderissem. o Simples Nacional, específico para microempresas e empresas de pequeno porte, foi instituído pela Lei no 9.317/1996 e consolidado pela Lei Complementar no 123/2006, que aprovou o estatuto correspondente a tais organizações. Além destes regimes de parcelamento integrantes de um programa federal, existem outros regimes inominados legalmente previstos, a exemplo do art. 38 da Lei no $8.212 / 1991$, dispositivo expressamente revogado pela lei do Refis da Crise, e do disposto na Lei no 10.522/2002, com a redação, atualmente, alterada por outros programas como o próprio Refis de 2009. Recentemente, o Congresso Nacional converteu a Medida Provisória no 627/2013 na Lei no 12.973/2014. Entre as diversas alterações promovidas na legislação tributária, este novo diploma legal reabriu o prazo instituído pelo Refis da Crise, demonstrando como os regimes de parcelamento continuam representando um instrumento presente na Administração Fiscal brasileira. Entre outros dispositivos que confirmam tais fatos na Lei no $12.973 / 2014$ : “Art. 93. A Lei no 12.865, de 9 de outubro de 2013, passa a vigorar com as seguintes alterações: 'Art. 17.0 prazo previsto no $\S 12$ do art. 10 e no art. 70 da Lei no 11.941, de 27 de maio de 2009, bem como o prazo previsto no $\S 18$ do art. 65 da Lei no 12.249, de 11 de junho de 2010, passa a ser o do último dia útil do segundo mês subsequente ao da publicação da Lei decorrente da conversão da Medida Provisória no 627, de 11 de novembro de 2013, atendidas as condições estabelecidas neste artigo. [...] §5 Aplica-se aos débitos pagos ou parcelados, na forma do art. 65 da Lei no 12.249, de 11 de junho de 2010, o disposto no parágrafo único do art. 4o da Lei no 11.941, de 27 de maio de 2009, bem como o disposto no §16 do art. 39 desta Lei, para os pagamentos ou parcelas ocorridos após 10 de janeiro de 2014. [...]" (sem grifos no original).

74 A lei que instituiu o Refis, Lei no 9.964/2000, inaugurou a lógica da suspensão e da extinção da exigibilidade do crédito tributário: “Art. 15. É suspensa a pretensão punitiva do Estado, referente aos crimes previstos nos arts. $1^{\circ}$ e $2^{\circ}$ da Lei no 8.137, de 27 de dezembro de 1990 , e no art. 95 da Lei no 8.212 , de 24 de julho de 1991, durante o período em que a pessoa jurídica relacionada com o agente dos aludidos crimes estiver incluída no Refis, desde que a inclusão no referido Programa tenha ocorrido antes do recebimento da denúncia criminal. $\S 1^{\circ} \mathrm{A}$ prescrição criminal não corre durante o período de suspensão da pretensão punitiva. $\S^{\circ} 0$ disposto neste artigo aplica-se, também: I - a programas de recuperação fiscal instituídos pelos Estados, pelo Distrito Federal e pelos Municípios, que adotem, no que couber, normas estabelecidas nesta Lei; II - aos parcelamentos referidos nos arts. 12 e 13. §3ํㅡㄹ Extingue-se a punibilidade dos crimes referidos neste artigo 
a empresa, após praticar crimes de natureza tributária, tem o direito de aderir aos regimes legais de parcelamento do débito. Nestes casos, operam-se, quanto à administração fazendária, a suspensão da exigibilidade do crédito e, quanto ao titular da ação penal e à autoridade judiciária competentes, a suspensão da pretensão punitiva do Estado. Em segundo lugar, após o integral pagamento do débito, os responsáveis legais pela prática do crime tributário não podem ser punidos, ou seja, mesmo que judicialmente comprovadas tipicidade, ilicitude e culpabilidade quanto aos fatos cometidos, nenhuma pena lhes poderá ser imputada. A flexibilidade, quanto a estes dois aspectos, decorre da não existência de correspondentes legais para os demais crimes, sobretudo no que tange à suspensão da pretensão punitiva do Estado. Os casos ordinários de reparação do dano - desistência voluntária e arrependimentos eficaz ou posterior - não geram suspensão ou extinção da punibilidade do crime praticado, ensejando, no máximo, causa de redução da pena. ${ }^{75}$

Há pesquisas na área das ciências econômicas que analisam o comportamento empresarial diante dos regimes legais de parcelamentos tributários existentes. ${ }^{76}$ As conclusões indicam que os efeitos decorrentes destes regimes são, no geral, negativos. O propósito para o governo criar condições flexíveis de parcelamento visa estimular o pagamento voluntário de tributos anteriormente avaliados como um déficit na arrecadação fiscal. O resultado, no entanto, de tais parcelamentos conduziu ao quadro oposto, pois “a expectativa de oferta de parcelamentos tributários no futuro,

quando a pessoa jurídica relacionada com o agente efetuar o pagamento integral dos débitos oriundos de tributos e contribuições sociais, inclusive acessórios, que tiverem sido objeto de concessão de parcelamento antes do recebimento da denúncia criminal." Neste momento, os benefícios legais somente alcançam hipóteses do crime de sonegação fiscal previsto em legislação específica e algumas condutas penalmente relevantes da Lei da Seguridade Social que sofreram readequação normativa típica, atualmente dispostas no art. 168-A do Código Penal. Posteriormente, a Lei do Refis da Crise, Lei no 11.941/2009, estendeu esta lógica a outros tipos penais: “Art. 67. Na hipótese de parcelamento do crédito tributário antes do oferecimento da denúncia, essa somente poderá ser aceita na superveniência de inadimplemento da obrigação objeto da denúncia. Art. 68. É suspensa a pretensão punitiva do Estado, referente aos crimes previstos nos arts. $10 \mathrm{e}$ $2^{\circ}$ da Lei $n^{\circ}$ 8.137, de 27 de dezembro de 1990, e nos arts. 168-A e 337-A do Decreto-Lei ํo 2.848, de 7 de dezembro de 1940 - Código Penal, limitada a suspensão aos débitos que tiverem sido objeto de concessão de parcelamento, enquanto não forem rescindidos os parcelamentos de que tratam os arts. 10 a 30 desta Lei, observado o disposto no art. 69 desta Lei. Parágrafo único. A prescrição criminal não corre durante o período de suspensão da pretensão punitiva. Art. 69. Extingue-se a punibilidade dos crimes referidos no art. 68 quando a pessoa jurídica relacionada com o agente efetuar o pagamento integral dos débitos oriundos de tributos e contribuições sociais, inclusive acessórios, que tiverem sido objeto de concessão de parcelamento. Parágrafo único. Na hipótese de pagamento efetuado pela pessoa física prevista no $§ 15$ do art. 1ํ desta Lei, a extinção da punibilidade ocorrerá com o pagamento integral dos valores correspondentes à ação penal." Com este novo diploma legal, a lógica passou a integrar, além das hipóteses de sonegação fiscal da Lei no 8.137/1990, os crimes de apropriação indébita previdenciária e de sonegação de contribuição previdenciária.

75 De acordo com o Código Penal: “Desistência voluntária e arrependimento eficaz Art. 15 - 0 agente que, voluntariamente, desiste de prosseguir na execução ou impede que o resultado se produza, só responde pelos atos já praticados. Arrependimento posterior Art. 16 - Nos crimes cometidos sem violência ou grave ameaça à pessoa, reparado o dano ou restituída a coisa, até o recebimento da denúncia ou da queixa, por ato voluntário do agente, a pena será reduzida de um a dois terços" (com grifos no original).

76 Cf. PAES, Nelson Leão. O Parcelamento Tributário e Seus Efeitos sobre o Comportamento dos Contribuintes. Revista Economia, Brasília, v. 13, n. 2, p. 345-363, 2012. Disponível em: <http://www.anpec.org.br/revista/ vol13/vol13n2p345_363.pdf>. Acesso em: 24 maio 2014. 
bem como as condições em que são colocados [...] afetam de forma negativa o recolhimento espontâneo hoje" ${ }^{77}$ Esta pesquisa demonstra graficamente tal redução no pagamento espontâneo de tributos após a criação dos regimes de parcelamentos instituídos a partir do ano 2000 indicando a ocorrência de efeitos diversos dos pretendidos.

Quanto ao terceiro aspecto, alguns critérios normativos foram desenvolvidos a fim de avaliar o custo-benefício do ajuizamento de execução fiscal, posteriormente estendidos à deflagração da ação penal correspondente. ${ }^{78} \mathrm{~A}$ jurisprudência, ao longo dos anos, autorizou a aplicação progressiva de tais critérios para fins de reconhecimento da insignificância penal de crimes tributários. Primeiramente, usava-se o critério para cancelamento da inscrição em Dívida Ativa da União, previsto na Lei no 10.522/2002: $\mathrm{R} \$ 100,00 .^{79} \mathrm{Em}$ seguida, o critério foi alterado para o valor estabelecido pela mesma lei para arquivar, sem baixa na distribuição, os processos de execução fiscal: $\mathrm{R} \$ 2.500,00 .^{80}$ Conceitualmente, foi mantida a aplicação deste critério normativo, mas, com a alteração da redação do art. 20 da Lei no 10.522/2002, promovida pela Lei no 11.033/2004, o limite para o reconhecimento da insignificância em crimes tributários se elevou para o quantum de $\mathrm{R} \$ 10.000,00$, corroborado pela Portaria do Ministério da Fazenda (MF) no 49/2004. ${ }^{81}$ Atualmente, já existe ato normativo da Administração Federal prevendo limite superior ao estabelecido pela Lei oㅜ 10.522/2002, o que gera certa divisão na jurisprudência. A Portaria MF no 75/2012 majorou o limite para não ajuizamento de execução fiscal para R\$20.000,00.82 A aplicação da insignificância com base neste ato normativo, porém, ainda não é pacífica. Embora a Administração Fiscal

77 PAES, Nelson Leão. O Parcelamento Tributário e Seus Efeitos sobre o Comportamento dos Contribuintes. Revista Economia, Brasília, v. 13, n. 2, p. 361, 2012. Disponível em: <http://www.anpec.org.br/revista/ vol13/vol13n2p345_363.pdf>. Acesso em: 24 maio 2014.

78 Nos casos de crimes tributários, há uma forte proximidade entre a ação fiscal e a ação penal, uma vez que a maior parte das denúncias oferecidas pelo Ministério Público na matéria se lastreia em uma Representação Fiscal para Fins Penais que tem sido reconhecida pela jurisprudência como peças de informação capazes de dispensar a instauração de inquérito policial, devido ao nível de detalhamento no trato da materialidade do ilícito praticado e de sua correspondente autoria.

79 De acordo com a Lei no 10.522/2002: “Art. 18. Ficam dispensados a constituição de créditos da Fazenda Nacional, a inscrição como Dívida Ativa da União, o ajuizamento da respectiva execução fiscal, bem assim cancelados o lançamento e a inscrição, relativamente: [...] $\$ 1^{\circ}$ Ficam cancelados os débitos inscritos em Dívida Ativa da União, de valor consolidado igual ou inferior a $R \$ 100,00$ (cem reais). [...]" (sem grifos no original).

80 De acordo com a redação original da Lei no 10.522/2002: “Art. 20. Serão arquivados, sem baixa na distribuição, os autos das execuções fiscais de débitos inscritos como Dívida Ativa da União pela ProcuradoriaGeral da Fazenda Nacional ou por ela cobrados, de valor consolidado igual ou inferior a $R \$ 2.500,00$ (dois mil e quinhentos reais)" (sem grifos no original).

81 De acordo com a Lei no 10.522/2002, com redação alterada pela Lei no 11.033/2004: “Art. 20. Serão arquivados, sem baixa na distribuição, mediante requerimento do Procurador da Fazenda Nacional, os autos das execuções fiscais de débitos inscritos como Dívida Ativa da União pela Procuradoria-Geral da Fazenda Nacional ou por ela cobrados, de valor consolidado igual ou inferior a $R \$ 10.000,00$ (dez mil reais). [...]" (sem grifos no original). De acordo com a Portaria do Ministério da Fazenda no 49/2004: “Art. 1ํ Autorizar: I - a não inscrição, como Dívida Ativa da União, de débitos com a Fazenda Nacional de valor consolidado igual ou inferior a R\$1.000,00 (mil reais); e II - o não ajuizamento das execuções fiscais de débitos com a Fazenda Nacional de valor consolidado igual ou inferior a $R \$ 10.000,00$ (dez mil reais). [...]" (sem grifos no original).

82 De acordo com a Portaria MF nำ 75/2012: “Art. 1ํDeterminar: I - a não inscrição na Dívida Ativa da União de débito de um mesmo devedor com a Fazenda Nacional de valor consolidado igual ou inferior a R $\$ 1.000,00$ (mil reais); e II - o não ajuizamento de execuções fiscais de débitos com a Fazenda Nacional, cujo valor consolidado seja igual ou inferior a $R \$ 20.000,00$ (vinte mil reais)" (sem grifos no original). 
tenha reforçado o caráter vinculante de sua diretriz - a atual portaria optou por "determinar”, não meramente “autorizar” o não ajuizamento da execução fiscal -, prevalece o entendimento no Superior Tribunal de Justiça de que o critério legal de $\mathrm{R} \$ 10.000$ deve ser mantido. ${ }^{83}$ A partir do ano de 2014 , no entanto, podem ser encontrados julgados em sentido diverso, indicando o que pode se definir, futuramente, como a jurisprudência consolidada sobre a matéria. ${ }^{84}$ Mesmo que não seja firmado tal entendimento, o critério normativo de $\mathrm{R} \$ 10.000,00$ aplicado aos crimes tributários para fins de reconhecimento da insignificância penal representa um valor desproporcional se comparado aos crimes patrimoniais previstos na legislação. ${ }^{85}$

83 Entre muitos outros precedentes, que repetem o teor de suas ementas, Cf. “AGRAVO REGIMENTAL NO RECURSO ESPECIAL. DESCAMINHO. PRINCÍPIO DA INSIGNIFICÂNCIA. INAPLICABILIDADE. PRECEDENTES. LEI N. 10.522/02. VALOR ELIDIDO SUPERIOR A R\$10.000,00 (DEZ MIL REAIS). PORTARIA N. 75/2012, DO MINISTÉRIO DA FAZENDA. DESCABIMENTO. I - A 3a Seção deste Superior Tribunal de Justiça, apreciando a questão da aplicação do princípio da insignificância ao crime de descaminho, no julgamento do Recurso Especial Representativo de Controvérsia n. 1.112.748/TO, sedimentou o entendimento segundo o qual somente é cabível o reconhecimento do delito de bagatela aos débitos tributários que não ultrapassem o teto de $\mathrm{R} \$ 10.000,00$ (dez mil reais), em conformidade com o art. 20 da Lei n. 10.522/2002. II - A Portaria n. 75, de 22 de março de 2012, do Ministério da Fazenda, não conduz à conclusão diversa. Se a execução fiscal pode prosseguir por valor inferior a $\mathrm{R} \$ 20.000,00$ (vinte mil reais), consoante a disciplina legal, então tal montante não pode ser considerado insignificante. III - In casu, o valor do tributo elidido é superior ao patamar fixado por esta Corte Superior. IV - Agravo Regimental improvido" (AGRESP no 201302547749, STJ, Quinta Turma, Min, Rel. Regina Helena Costa, DJE, 14 maio 2014).

84 Exemplificando o entendimento, ainda minoritário, Cf. “[...] APROPRIAÇÃO INDÉBITA PREVIDENCIÁRIA. [...] PRINCÍPIO DA INSIGNIFICÂNCIA: INAPLICABILIDADE. [...] EXTINÇÃO DA PUNIBILIDADE PELO PARCELAMENTO: INVIABILIDADE. PARCELAMENTO REQUERIDO NA VIGÊNCIA DA LEI 9.964/2000. SUSPENSÃO DO CURSO DO PROCESSO. [...] 1. Apelação da Defesa contra sentença que condenou os réus como incursos no artigo 168-A, $\S 1^{\circ}$, inciso I, na forma do artigo 71, do Código Penal às penas de 02 anos, 04 meses e 24 dias de reclusão. [...] 6. A Lei 10.522/2002, em seu artigo 20, com a redação dada pela Lei no $11.033 / 2004$, afastou a execução de débitos fiscais de valor igual ou inferior a $\mathrm{R} \$ 10.000,00$, demonstrando a falta de interesse fiscal da Administração Pública relativo a tributos que não ultrapassem este limite monetário. E a Portaria MF no 75 , de 22/03/2012, majorou o valor anteriormente fixado para $\mathrm{R} \$ 20.000,00$. Verifica-se o valor da contribuição previdenciária não recolhida, desconsiderado juros de mora e multa, para fins de aplicação do princípio da insignificância. Precedentes da Primeira Turma do Tribunal Regional Federal da 3a Região. 7. Verifica-se das LCD's que os débitos perfazem um total de $R \$ 43.024,25$, desconsiderados juros e multa, e que a Procuradoria Regional da Fazenda informou que os pagamentos efetuados pela empresa no programa de recuperação fiscal - REFIS, totalizaram o montante de $\mathrm{R} \$ 6.210,63$, de modo que o débito remanescente não comporta a aplicação do princípio da insignificância. [...]" (ACR no 00028017720024036181, TRF-3, Primeira Turma, Rel. Juiz Convocado Márcio Mesquita, e-DJF3, 10 fev. 2014). Neste caso, em particular, o princípio da insignificância não foi aplicado devido ao valor, mesmo com abatimento relativo ao regime do Refis e descontados juros e multas, ser superior a $\mathrm{R} \$ 20.000,00$.

85 Como exemplo de rigorosa aplicação do princípio da insignificância aos crimes patrimoniais, em plena dissonância de sua incidência nos crimes tributários, pode ser referida a decisão a seguir do STF: “HABEAS CORPUS. PRINCÍPIO DA INSIGNIFICÂNCIA. INAPLICABILIDADE AO CASO. LESÃO RELEVANTE A BEM JURÍDICO TUTELADO. [...] ORDEM DENEGADA. 1. O princípio da insignificância ou da bagatela somente pode ser aplicado quanto ausente lesão relevante a um bem jurídico tutelado. Precedentes (HC 84.4 12, 2ª T., Celso de Mello, DJ 19.11.04; Al-Q0 559904, Relator(a): Min. SEPÚLVED A PERTENCE, julgado em 07/06/2005, publicado em 26/08/2005, Primeira Turma). 2. In casu: (i) o paciente foi condenado à pena de 01 (um) ano de reclusão, em regime inicial aberto, convertida em pena restritiva de direitos pelo prazo de 02 (dois) anos, como incurso no artigo 240, caput, do Código Penal Militar ("Furto simples - Art. 240. Subtrair, para si ou para outrem, coisa alheia móvel: Pena - reclusão, até seis anos"), sob a acusação de ter subtraído para si 01 (um) aparelho de telefone celular usado, avaliado pelo preço médio de $\mathrm{R} \$ 430,00$ (quatrocentos e trinta reais) por laudo pericial cuja cópia foi acostada à exordial; [...] o impetrante, alega, ainda que o fato é atípico, em razão do princípio da insignificância, argumento que não deve prevalecer, porquanto o bem subtraído, segundo laudo pericial, é avaliado em $R \$ 430,00$ (quatrocentos e trinta reais), valor superior ao salário mínimo nacional vigente à época dos fatos ( $R \$ 350,00$ - trezentos e cinquenta reais). 3. Ordem denegada" (HC no 108211, STF, Primeira Turma, Min. Rel. Luiz Fux, DJ, 18 out. 2011, sem grifos no original). 
Desse modo, a flexibilidade da legislação penal tributária demonstra como a capacidade de organização da categoria empresarial também tem sucesso em defender seus interesses profissionais aprovando um regime criminal mais brando do que o regularmente aplicado. Embora o escopo da presente pesquisa se concentre na capacidade da bancada empresarial de conservar o status quo legislativo, é preciso ressaltar que a teoria dos veto players também considera a possibilidade de alterações incrementais na legislação. Trata-se da modificação oferecida ao Legislativo ou por ele proposta que visa aperfeiçoar as condições do interessado. No caso da legislação dos crimes tributários, as propostas advêm de Medidas Provisórias editadas pelo Chefe do Executivo Federal, que atua como montador de agenda, e, por se adequarem às preferências da bancada empresarial, são aprovadas por este veto player. Em tais circunstâncias, não se trata, especificamente de conservar conquistas políticas da categoria. 0 próprio incremento obtido representa uma conquista política a ser doravante preservada.

Apesar dos esforços de grandes segmentos da sociedade, indicando o clamor por reformas e melhorias na promoção e na garantia de seus direitos, o interesse de elites minoritárias do País que dominam o sistema político por sua elevada capacidade de organização política parece ter prevalecido. A categoria empresarial, que representa minoria populacional, obteve um quórum parlamentar de quase $46 \%$ (quarenta e seis por cento), suficiente para impedir a aprovação das propostas que tendam a prejudicar seus interesses econômicos - e, em algumas ocasiões, restaurar condições mais vantajosas ou autorizar incrementos do status quo legislativo que Ihes sejam convenientes. Com essa distorção majoritária, a bancada empresarial associada à atuação da $\mathrm{CNI}$ - teve sucesso em suas tentativas de conservar conquistas políticas alcançadas pela categoria que representa, e os exemplos explorados acima comprovam a eficiência desta forma supramajoritária de organização política.

\section{Conclusão}

A presente pesquisa analisou o comportamento da bancada empresarial no Congresso Nacional. O Poder Legislativo foi abordado partindo-se do princípio de que sua composição não corresponderá, necessariamente, às proporções dos diversos grupos existentes na sociedade, já que a capacidade de organização política de alguns segmentos pode conduzir a uma distorção majoritária. Com base nesta problemática, a pesquisa se aproximou da teoria dos veto players, que fornece recursos epistemológicos para compreender sistemas políticos como o brasileiro. Embora esta seja uma teoria pretensamente genérica e amparada por consistentes elementos empíricos, foi apresentada a crítica da emergência, indicando que, em determinados momentos, a composição ontológica do sistema político sob análise poderia observar 
variações significativas. Preferências ou mesmo os atores políticos podem emergir dependendo da matéria, do assunto ou do projeto em discussão.

Nesse sentido, após concluir a pesquisa parece plausível sustentar que resta confirmada a hipótese inicialmente estabelecida - a bancada empresarial, que atua no Congresso Nacional, assumiu a posição de um verdadeiro veto player no sistema político brasileiro. Quando matérias que se chocam com os interesses da categoria empresarial, sobretudo no que concerne a direitos e garantias trabalhistas ou tributação, é possível observar uma relevante emergência de um ator político munido de um poderoso poder de veto no sistema brasileiro. Este poder de veto da bancada empresarial, que, em tese, corresponde a $46 \%$ (quarenta e seis por cento) aproximadamente de todo o Legislativo, é reiteradamente confirmado nos casos que provocam sua emergência.

O sucesso da bancada empresarial em conservar as conquistas políticas de sua categoria no Congresso Nacional, com auxílio da CNI, pode ser destacado em alguns casos emblemáticos. Em sua maior parte, o comportamento constatado da bancada tem caráter conservador, também havendo exemplo de comportamentos de restauração ou de autorização de mudança incremental no status quo legislativo. Com isso, a bancada empresarial foi capaz de conservar seus interesses ao conter propostas políticas como (i) a redução da jornada semanal de trabalho para 40 (quarenta) horas, além do aumento do adicional da hora extraordinária para $75 \%$ (setenta e cinco por cento) sobre a hora normal de trabalho; (ii) a proibição da dispensa imotivada; (iii) a instituição de nova base de cálculo para o adicional de insalubridade diante da inconstitucionalidade de sua indexação ao salário-mínimo; (iv) a punição da prática da retenção dolosa de salário pela inexistência de lei; e (v) a instituição de cobrança e fiscalização do IGF. Além do comportamento conservador, a bancada empresarial viabilizou a restauração do status quo ante em (vi) relação à base de cálculo do adicional de periculosidade de eletricitários ao revogar sua regulamentação específica mais vantajosa, também permitindo mudanças incrementais (vii) ao flexibilizar as normas de prevenção e repressão dos crimes tributários.

Em síntese, a pesquisa parece ter atendido ao objetivo previamente estabelecido no sentido de demonstrar o impacto da capacidade de organização política de grupos minoritários da sociedade em detrimento dos interesses de segmentos mais numerosos da sociedade.

The Veto Power of Entreprenous in the Congress: an Emergent Veto Player in the George Tsebelis' Theory

Abstract: This article starts from the problem now titled majoritarian distortion, characterized basically when representative institutions are dominated by elites or minority groups in society due to their higher political organization capacity. In this logic, the entrepreneur bench present in the Brazilian National Congress is specified as main object. The hypothesis formulated questions whether this bench would have assumed the role of veto players in the Brazilian political system. Starting from the theory of George Tsebelis (theory 
of veto players) and criticizing it for failing to predict the possibility of emergence of preferences or different political actors in concrete situations, some emblematic cases are investigated in order to confirm the performance of this form of superpartisan organization. In particular, stands out the conservative nature of the bench behavior. The objective of this research is to demonstrate how elite or minority groups can impact policy at the expense of the interests of more numerous segments of society.

Key words: Constitutional Design. Legislative Branch. Veto Players Theory. Entrepreneurs Bench. Institutional Behavior.

\section{Referências}

ALVARENGA, Rúbia Zanotelli de. Organização Internacional do Trabalho e a Proteção aos Direitos Humanos do Trabalhador. Disponivel em: <http://www.faculdade.pioxii-es.com.br/img/artigos/ artigo_rubia.pdf>. Acesso em: 26 maio 2014.

ALVES. Rafael César. Redução da jornada de trabalho de 44 para 40 horas semanais: análise à luz da proposta de emenda à constituição 231/1995. ANIMA: Revista Eletrônica do Curso de Direito das Faculdades OPET, ano III, n. 7, 2012.

ARAÚJO JÚNIOR, Francisco Milton. A monetização do trabalho, antinomia constitucional e a base de cálculo do adicional de insalubridade. Disponível em: <http://www.hocupacional.com.br/novo/images/ upload/artigos/monetiza\%E7\%E3o\%20do\%20trabalho\%20insalubre.pdf>. Acesso em: 24 mar. 2014.

BALKIN, Jack. What Brown teaches us about constitutional theory. Virginia Law Review, v. 90, 6, 2004.

CAMPAGNOLI, Adriana de Fátima Pilatti Ferreira; MANDALOZZO, Silvana Souza Netto. Uma (re)leitura do art. 7ํㅡ, XXIII, da Constituição da República - possíveis alternativas para a monetização do risco com enfoque em atividades insalubres. In: NASCIMENTO, Grasiele Augusta Ferreira; MISAILIDIS, Mirta Gladys Lerena Manzo de; BACARAT, Eduardo Milléo (Coord.). Direito do Trabalho - XXII Encontro Nacional do CONPEDI. Florianópolis: FUNJAB, 2013.

CONFEDERAÇÃO NACIONAL DA INDÚSTRIA (CNI). Agenda Legislativa da Indústria. Brasília: Confederação Nacional da Indústria, 2014. Disponível em: <http://www.portaldaindustria.com.br/cni/canal/agendalegislativa-home/>. Acesso em: 24 abr. 2014.

DARONCHO, Leomar. Adicional de insalubridade: entre a monetização da saúde do trabalhador e o direito fundamental ao meio ambiente de trabalho hígido. Rio de Janeiro: FIOCRUZ, 2012. Disponível em: <http://aplicacao.tst.jus.br/dspace/bitstream/handle/1939/25601/2012_daroncho_leomar. pdf?sequence=1>. Acesso em: 24 mar. 2014.

DEPARTAMENTO INTERSINDICAL DE ASSESSORIA PARLAMENTAR (DIAP). Bancadas Informais no Congresso Nacional em 2011. Radiografia do Novo Congresso: Legislatura 2011-2015. Brasília: Departamento Intersindical de Assessoria Parlamentar, 2010. Disponivel em: <http://www.diap.org. $\mathrm{br}$ / diap/images/stories/publicacoesDIAP/Radiografia_011/Radiografia_011_P35.pdf>. Acesso em: 25 abr. 2013.

KRISLOV, Samuel. The Amicus Curiae Brief: from Friendship to Advocacy. Yale Law Journal, v. 72, 694, 1962-193.

LEÃO, Priscila Muñoz. Proteção Jurídica do Salário e o Artigo 7o, Inciso X da CRFB. 2013. 66 f. Monografia (Graduação em Direito) - Universidade Federal do Rio de Janeiro, Rio de Janeiro, 2013.

LEVINSON, Daryl; PILDES, Richard. Separation of Parties, Not Powers. Harvard Law Review, v. $119,1,2006$.

LOWMAN, Michael. The Litigating Amicus Curiae: when does the party begin after the friends leave. The American University Law Review, v. 41, 1243, 1992. 
MEDINA, Damares. Amicus curiae - amigo da corte ou amigo da parte? São Paulo: Saraiva, 2010.

OLIVEIRA, Rosane Cristina de. Empresariado e Congresso Nacional: um estudo das novas estratégias de ação política: a Firjan e a CNI nos anos 90. Dissertação (Mestrado) - UFRJ/IFCS/Programa de Pós-graduação em Ciência Política. 141 fl. Rio de Janeiro: UFRJ/IFCS, 2002. Disponível em: <http:// www.livrosgratis.com.br/arquivos_livros/cp027789.pdf>. Acesso em: 25 abr. 2014.

PAES, Nelson Leão. O Parcelamento Tributário e Seus Efeitos sobre o Comportamento dos Contribuintes. Revista Economia, Brasília, v. 13, n. 2, p. 345-363, 2012. Disponível em: <http:// www.anpec.org.br/revista/vol13/vol13n2p345_363.pdf>. Acesso em: 24 maio 2014.

POST, Robert; SIEGEL, Reva. Roe Rage: Democratic Constitutionalism and Backlash. Harvard Civil Rights-Civil Liberties Law Review, v. 42, 373, 2007.

SIQUEIRA NETO, José Francisco. Direito do Trabalho e Flexibilização no Brasil. São Paulo em Perspectiva, v. 11, n. 1, 1997.

TSEBELIS, George. Veto Players: How Political Institutions Work. Princeton: Princeton University Press, 2002.

VERMEULE, Adrian. The System of the Constitution. New York: Oxford University Press, 2011.

Informação bibliográfica deste texto, conforme a NBR 6023:2002 da Associação Brasileira de Normas Técnicas (ABNT):

RANGEL, Henrique; BOLONHA, Carlos; FARONI, Fabrício. 0 poder de veto da bancada empresarial no Congresso: um veto playeremergente na teoria de George Tsebelis. A\&C - Revista de Direito Administrativo \& Constitucional, Belo Horizonte, ano 15, n. 61, p. 145-179, jul./set. 2015.

Recebido em: 13.03.2015

Aprovado em: 17.05.2015 